Article

\title{
Auction Mechanism of Micro-Grid Project Transfer
}

\author{
Yong Long ${ }^{1}$, Yu Wang ${ }^{1, *}$ and Chengrong Pan ${ }^{1,2}$ \\ 1 School of Economics and Business Administration, Chongqing University, Chongqing 400030, China; \\ longyong@cqu.edu.cn (Y.L.); panchengrong@cqu.edu.cn (C.P.) \\ 2 School of International Business, Sichuan International Studies University, Chongqing 400031, China \\ * Correspondence: yu.wang@cqu.edu.cn
}

Received: 12 September 2017; Accepted: 19 October 2017; Published: 20 October 2017

\begin{abstract}
Micro-grid project transfer is the primary issue of micro-grid development. The efficiency and quality of the micro-grid project transfer directly affect the quality of micro-grid project construction and development, which is very important for the sustainable development of micro-grid. This paper constructs a multi-attribute auction model of micro-grid project transfer, which reflects the characteristics of micro-grid system and the interests of stakeholders, calculates the optimal bidding strategy and analyzes the influence of relevant factors on auction equilibrium by multi-stage dynamic game with complete information, and makes a numerical simulation analysis. Results indicate that the optimal strategy of auction mechanism is positively related to power quality, energy storage quality, and carbon emissions. Different from the previous lowest price winning mechanism, the auction mechanism formed in this paper emphasizes that the energy suppliers which provide the comprehensive optimization of power quality, energy storage quality, carbon emissions, and price will win the auction, when both the project owners and energy suppliers maximize their benefits under this auction mechanism. The auction mechanism is effective because it is in line with the principle of individual rationality and incentive compatibility. In addition, the number of energy suppliers participating in the auction and the cost of the previous auction are positively related to the auction equilibrium, both of which are adjusting the equilibrium results of the auction. At the same time, the utilization rate of renewable energy and the comprehensive utilization of energy also have a positive impact on the auction equilibrium. In the end, this paper puts forward a series of policy suggestions about micro-grid project auction. The research in this paper is of great significance to improve the auction quality of micro-grid projects and promote the sustainable development of micro-grid.
\end{abstract}

Keywords: micro-grid; project resource transfer; multi-attribute reverse auction; project owner; energy supplier

\section{Introduction}

As an important form of smart grid, micro-grid has received large attention in recent years. As a new type of power generation, distribution, and selling system, micro-grid can include distributed generation, thus to improve utilization rate of renewable energy and clean energy, reduce power system carbon emissions [1]. At the same time, the collaboration between micro-grid and large grid can improve the reliability and security of power systems to reduce the occurrence of large-scale power outages and to enhance the experience of using electricity. Due to these features and advantages of micro-grids, many countries have decided to promote the development of micro-grid projects in order to promote energy conservation, carbon emissions reduction, as well as structural reform of energy supply and to achieve sustainable energy development strategies. The European Union, the United States, Japan, and other countries have issued relevant policies and supportive plans one after another to promote the development of micro-grid projects [2-4]. At the same time, China's 
energy development goals for 2020 and the Thirteenth Five Year Plan for Electricity Development also incorporate micro-grids as an important way of energy restructuring and power system reform to encourage the construction and development of micro-grid projects [5,6].

As the society pays more attention to micro-grid, the academic research on micro-grid is increasing year by year. One part of existing research on the micro-grid focuses on technical issues, such as, the power system [7], energy storage technology [8], control and protection technology $[9,10]$, energy exchange technology [11], micro-grid system optimization [12,13], and other key technologies. The other part studies micro-grid system from the perspective of economy and management, including configuration decision-making model [14,15], costs and benefits of investment in micro-grid [16], performance analysis of micro-grid [17], social welfare effects of micro-grid [18], and cooperation among stakeholders of micro-grid [19]. However, when compared with other aspects of micro-grid research, research from the perspective of micro-grid project transfer is still relatively scarce. Micro-grid project transfer is very important for the construction and development of micro-grid. When developing a micro-grid project, only the owner of micro-grid project has transferred project to participants so as to involve them in the process. Project transfer as an important way to allocate resources, improve market efficiency, and achieve Pareto optimality, with the development of practice it will play an increasingly important role in the development of micro-grid. However, due to the fact that the micro-grid is still in the early stages of development, the corresponding mechanism of micro-grid project transfer is still relatively scarce. The mechanism of micro-grid project transfer now is mainly borrowed from the large grid. When compared with large grid, micro-grid has different characteristics of technology and market, so these mechanisms are not suitable for micro-grid project transfer, and are not conducive to the resources allocation and development of micro-grid. The socio-technical systems approach argues that the organization's technical system determines the management of organization [18]. Micro-grid's technology system is different from the large grid, so that micro-grid project transfer requires different mechanisms. At the same time, the stakeholder theory argues that because the organization involves many stakeholders, the organization's system needs to balance the interests of various stakeholders [19]. When transferring a micro-grid project, the micro-grid's market characteristics make micro-grid project transfer involves many participants. Since different stakeholders have different interests demand, if the transfer mechanism does not balance the interests of all parties, it will seriously affect the quality of project transfer and development of micro-grid. Therefore, micro-grid project transfer requires corresponding transfer mechanism to balance the interests of stakeholders. However, due to micro-grid market has the characteristics of monopoly and externality, these characteristics make resource allocation inefficient and market failure in the micro-grid market, which makes the micro-grid market cannot automatically generate effective transfer mechanism. Especially in the early development of micro-grid, these factors make the micro-grid market inefficiency, so that micro-grid market cannot automatically achieve Pareto optimality. The lack of project transfer mechanism seriously affects the development of the micro-grid. In order to promote the application and popularization of micro-grid, it is necessary to study the transfer of micro-grid project and design the corresponding transfer mechanism to promote the project transfer and the sustainable development of micro-grid.

For the transfer of micro-grid project, auction is a suitable mechanism [20-22]. Compared with feed-in tariffs which can rapidly increase the utilization rate of renewable energy, auction can better control cost and improve the quality of project implementation, which facilitates the development of energy projects [23]. At the same time, national policies also encourage the adoption of open bidding, competitive negotiation, competitive consultation, and other ways to determine the undertaker of energy projects in order to regulate the development of energy projects [2,24]. Since that micro-grid project has many important attributes, we use the multi-attribute reverse auction theory to study this problem. Different from the single attribute auction that emphasizes the lowest price winning mechanism, ignores the importance of other attributes of the project, the multi-attribute reverse auction theory takes into full consideration the important performance of the project's other attributes, thus to 
better control the quality of the auction [25]. Multi-attribute reverse auction is widely used in product procurement and bidding in large enterprise, which can effectively save the procurement costs and enhance the procurement efficiency of enterprises [26]. Multi-attribute reverse auction is also widely used in the auction of power system resources. For example, Kreiss et al. [24] studied the auction of renewable energy projects, advocating for the use of financial, physical requirements, and penalties to ensure project fulfillment of the auction winner, to enhance the implementation quality of the renewable energy project. Fang et al. [27] used a multi-attribute reverse auction to study the auction of electricity purchase, insisting that when purchasing electricity, the large grid should consider not only price but also the carbon emissions of the power generation company so as to enhance the quality of auction in electricity purchase. The application of multi-attribute auction theory in electricity auction, effectively enhances the corresponding power project's auction quality. From the above analysis, we can see that the multi-attribute auction mechanism not only pays attention to the price, but also pays attention to other aspects of the project, which can effectively improve the quality of the project auction. Therefore, for the transfer of micro-grid project, the multi-attribute auction is a good analytical method, can effectively solve related issues of the micro-grid project transfer $[23,28]$.

Therefore, in order to study the micro-grid project transfer and design the corresponding transfer mechanism, we construct a multi-attribute auction model that reflects the characteristics of micro-grid system and the interests of stake holders. We extend the auction model from the existing quality and price attributes to four attributes: power quality, energy storage quality, carbon emissions, and price. Our research is not a simple extension of the previous research, but redesigns the auction model and variables based on the characteristics of micro-grid system and the interests of stakeholders, reconstructs the utility function and return function with the combination of power quality, energy storage quality, and carbon emissions, and distinguishes different types of energy suppliers with three variables as parameters, so as to derive the optimal strategy. At the same time, we analyze the impact of physical quality factors and the sunk costs of auction process on micro-grid auction in our model. The analysis results of the model are of great significance for the project owners to construct appropriate auction mechanism to transfer micro-grid project and for energy suppliers how to participate in the auction of micro-grid project.

The rest of the paper is arranged as follows: Section 2, introduces literature review; In Section 3, we introduce the assumptions, build the models, and analyze auction mechanisms based on multi-stage dynamic game; In Section 4, we perform a numerical analysis to further analyze auction strategy; In Section 5, we draw the conclusions.

\section{Literature Review}

Some scholars have studied the transfer of micro-grid project from different perspectives. In the early development of the micro-grid, due to the lack of transaction mechanism is the main problem, so early researches mainly focused on how to transfer micro-grid project [20], and through research to find the appropriate mechanisms of transferring in different situations [21,22]. For example, Alibhai et al. [20] studied the auction of distributed energy resources of micro-grid and analyzed the selection of auction mode under different scenes. Maity et al. [21] studied the auction bidding mechanism of power resources for micro-grid system, the study showed that single price bidding and discrimination price bidding could effectively reduce the cost of consumers and increase the revenue of micro-grid. Mayr et al. [22] studied the issues of photovoltaic power generation in Australian rooftops using reverse auction theory, the research indicated that reverse auction method was beneficial to increasing energy output and reduce government expenditure.

Along with progress in this study field, scholars have gradually turned to the problem and efficiency of transfer mechanism of micro-grid project, through the summary and discovery of the problem [29], aiming to optimize transfer mechanism and improve transfer efficiency [30,31]. For instance, Mastropietro et al. [29] found a significant difference between renewable energy power auctions rules and traditional power auction rules in South America area, designed a corresponding 
auction mechanism to improve the auction efficiency of renewable energy generation. Kylili et al. [30] analyzed a case of renewable energy auction in Cyprus and found the defects of the auction mechanism and put forward the corresponding improvement suggestions to promote competitive auction of renewable energy utilization. Marufu et al. [31] designed corresponding exception handling mechanism to detect fraud of electricity auction for micro-grid market and to improve the reliability and stability of the micro-grid under the resource constrained condition.

Recently, the problems that arise after the auction such as non-implementation and financing difficulties have driven scholars to focus on the quality of auction. Therefore, scholars have gradually deepened their research into the transfer mechanism, thus to design appropriate transfer mechanism, improve the quality of transferring micro-grid projects, and promote the sustainable development of micro-grid [32-36]. For example, Ferruzzi et al. [32] studied on optimal bidding in energy market for micro-grid under uncertainty, found that the optimal bidding strategy depending on renewable energy production. Eberhard et al. [33] investigated the effect of competitive auction on renewable energy utilization in South Africa, found that the auction reduced the cost of renewable energy power generation and improved the success rate of project finance, promoted the utilization of renewable energy, summarized relevant auction policy that can be used for other countries. Atalay et al. [34] studied support mechanisms of renewable energy of the Gulf, identified implementation support conditions of feed-in tariff and renewable energy auction in the Gulf, and identified success conditions of both methods in the Gulf. Gephart et al. [35] discussed the balance between high project implementation rate and minimize bidders risk, analyzed the influence of different factors on the renewable energy auction, and provided a reference for designing effective auction mechanism. Voss et al. [36] studied the auction strategy and bidding strategy of renewable energy in Germany, and found that the first price auction could obtain extra profits, also found that the influence of uncertainty of investment cost on the project value depended on the auction parameter values [36].

Through the literature review, we can see that how to improve the quality of micro-grid project transfer and how to promote the sustainable development of the micro-grid are the trend of current research. It is worth mentioning that the existing research about micro-grid project transfer mainly comes from the perspective of problem and optimization of auction mechanism, and is in lack of research from the perspective of micro-grid system characteristics and interests of stakeholders. Although the improvement of the auction system is very important, the auction mechanism unable to reflect the characteristics of the micro-grid system will seriously affect the quality of the auction. At the same time, the interests of micro-grid stakeholders are different. If project transfer mechanism cannot balance the interests of stakeholders, it will seriously affect the quality of micro-grid project auction. Therefore, we build an auction model that reflects the characteristics of micro-grid system and interests of stakeholders to study the transfer of micro-grid project, thus to improve the quality of micro-grid project transfer and promote the rational and healthy development of micro-grid.

\section{Multi-Attribute Auction for Micro-Grid Project Transfer}

\subsection{Variable Description of Micro-Grid Project Auction}

Using multi-attribute auction theory to study the transfer of micro-grid projects, an important issue is to identify which attributes of the micro-grid project are involved in the auction. Existing literature generally studied the auction of power project resources only from the attributes of tender bidding price and bidding quality [27,28]. These attributes can neither well reflect the characteristics of micro-grid system and the interests of stakeholders, nor to be conducive to further analyze strategy adopted by participants. Expand existing research, based on the characteristics of micro-grid system and the interests of stakeholders, we decide to introduce important quality attributes of the micro-grid project including power quality, energy storage quality, and carbon emission into the auction model.

Power quality refers to the quality of power technology and power configuration. Since power is the basis of grid system, power technology, and power configuration are the core of micro-grid 
system. The power of micro-grid is mainly generated by photovoltaic, wind and gas, emphasizing local production, and consumption of energy. In the meantime, micro-grid can also effectively and fully utilize local energy resources according to the characteristics of local energy with the help of corresponding power technologies such as biomass power generation and waste heat power generation. According to the characteristics of the local power resources and technology, we can rationally configure the power supply of micro-grid. This way not only can take the advantage of local energy resources and technical resources, but it can also facilitate the establishment of the micro-grid development mode of local characteristics. Therefore, we introduce power quality as a key quality factor of micro-grid into the auction model.

Energy storage quality refers to the quality of energy storage technology and energy storage configuration of micro-grid system. Because of the volatility of micro-grid power supply and the fluctuation of electricity load, energy storage is an important way to cut and fill valley and make full use of energy, which makes it an integral part of micro-grid. When micro-grid stores energy with super capacitors, lithium batteries, lead-acid batteries, and other batteries, according to its specific needs on hot and cold power, it can make comprehensive use of new storage methods such as water storage, ice storage, joint energy storage station, electric car charging, and other innovative energy storage methods. In this way, it will enrich energy storage of micro-grid, and will also improve the efficiency of energy use. These innovative energy storage methods and technologies are important parts of balancing energy supply and utilization of micro-grid and a key quality factor of micro-grid. Therefore, we also incorporate energy storage quality into the auction model.

Carbon emissions refer to the level of carbon emissions in micro-grid systems. Carbon emission is a big concern of micro-grid system. This is partly due to that besides renewable energy and clean energy, the rest of its power supply is mainly coal, which will produce a lot of carbon emissions $[8,9]$. The other reason is that when it exchanges electricity with large grid, micro-grid system will produce more carbon emissions as power consumer since that power generation of large grid is mainly coal-based. In view of this, in order to highlight the importance of the micro-grid on carbon emissions reduction, regulation rules of micro-grid pointed out that the annual exchange of electricity between grid-connected micro-grid and the external grid should be kept within no more than $50 \%$ of the annual power consumption, emphasizing the renewable energy installed capacity of micro-grid should account for more than $50 \%$ of the maximum load, or more than $70 \%$ of the comprehensive utilization rate of energy [1].Therefore, in order to highlight the importance of carbon emissions and the environmental benefits of micro-grid systems, we add carbon emissions as a decision-making variable to the model.

\subsection{Problem Description of Micro-Grid Project Auction}

Micro-grid project owners, such as government agencies, industrial parks, residential areas, and large users, possess micro-grid project resources. Due to lack of professional skills they cannot complete the construction of micro-grid alone. In order to alleviate the cost-benefit pressure of micro-grid project development, and promote the construction and development of micro-grid project, the project owners as resource holders will auction their projects and seek partners to search the best way to develop micro-grid projects. By auctioning the franchise or other project resources of the micro-grid project, project owners cooperate with other parties to complete the development of micro-grid projects through complementary resources and sharing professional efficiency.

The auction of micro-grid project is divided into four stages. In the first stage, the micro-grid project owners publish announcement of tender based on their own needs, and imply their own preference $\mathrm{v}_{\mathrm{q}}, \mathrm{v}_{\mathrm{s}}, \mathrm{v}_{\mathrm{e}}$ for power quality, $\mathrm{q}$, energy storage quality, $\mathrm{s}$, and carbon emissions, e, as well as pre-bid costs, $C_{\mathrm{f}}$, and acceptable maximum levels of carbon emissions, E. In the second stage, micro-grid energy suppliers, represented by grid companies, equipment suppliers, energy investors decide whether or not to participate in the bidding of micro-grid project according to project owner's tendering plan, unit power quality $\cos t, \mathrm{c}_{\mathrm{q}}$, unit energy storage quality cost, $\mathrm{c}_{\mathrm{s}}$, and carbon emissions 
cost, $c_{e}$, etc. If micro-grid energy suppliers choose to bid, then carry out research, design bidding plan, prepare bidding documents, and submit bidding scheme. The bidding scheme is a row vector consisting of power quality, energy storage quality, and carbon emissions and prices. In the third stage, owner of the micro-grid project sets up an expert team to evaluate the bid, choose the bid winner according as to whether the bidding program meets the needs and objectives of project owner and what technical type the energy supplier possesses. In the fourth stage, micro-grid project owner and the winning energy supplier discuss cooperation detail sand sign a formal contract, micro-grid project transfer auction process ends. The auction process of micro-grid project transfer is shown in Figure 1.

After the project owner announces the tender plan for the micro-grid project, what is the optimal strategy for energy supplier bidding? How does the project owner choose an energy supplier? And what factors will affect and how they will affect the micro-grid project auction? In order to explore these problems, we construct the following game model.

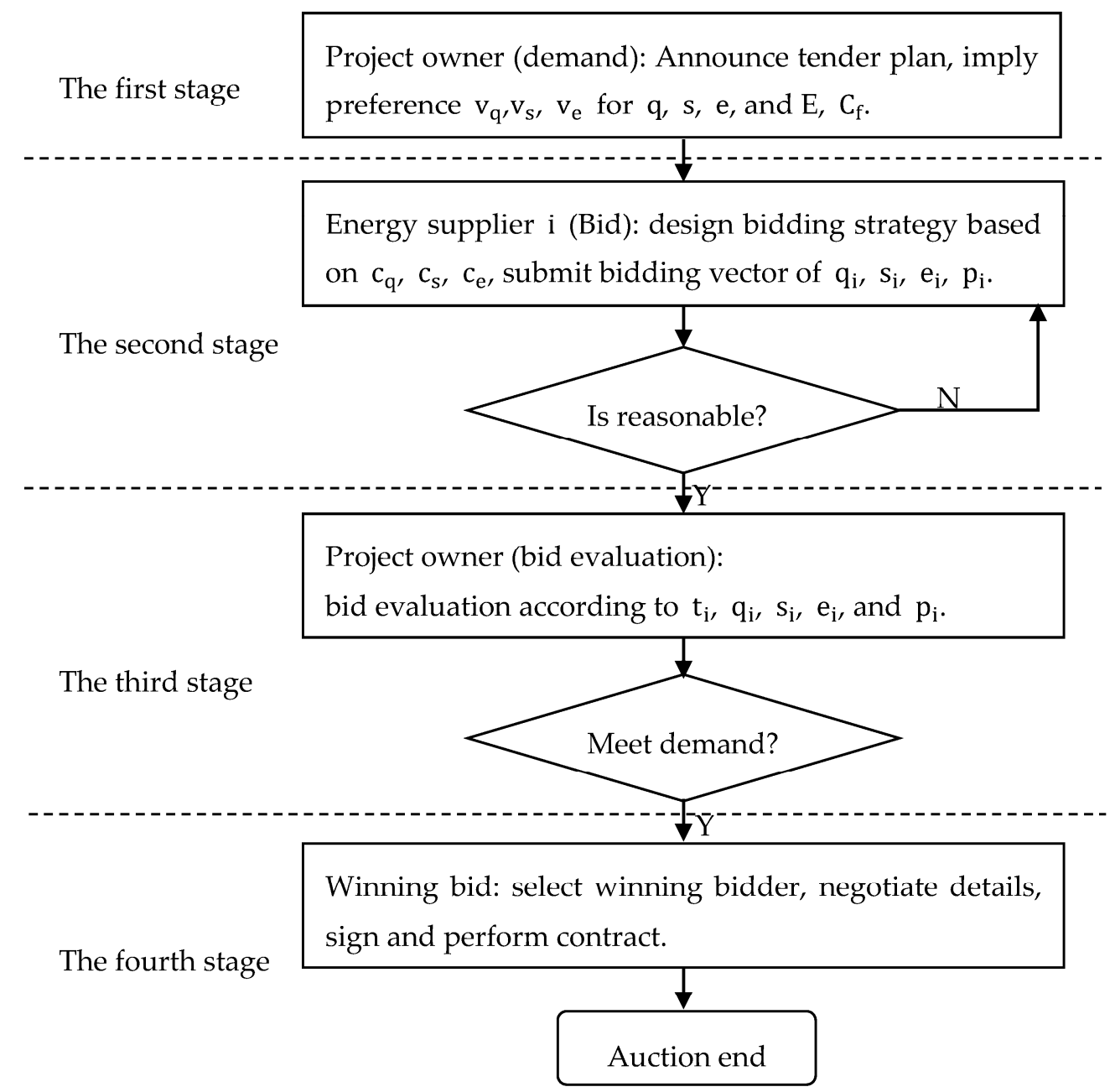

Figure 1. Multi-attribute auction flow chart of micro-grid project transfer.

\subsection{Auction Assumptions and Model Establishment}

After knowing project owner's tender plans and preferences, there are some energy suppliers, $\mathrm{n}$, participate in the bidding for micro-grid projects. Power quality, energy storage quality, carbon emissions and prices provided by energy suppliers $i(i=1 \ldots n)$ are expressed as $q_{i}, s_{i}, e_{i}$, and $p_{i}$.

Hypothesis 1. The power quality $q_{i}$, energy storage quality $s_{i}$ and carbon emissions $e_{i}$ are independent of each other, and are the continuous increasing function on $\left[q_{l}, q_{h}\right],\left[s_{l}, s_{h}\right]$ and $\left[e_{l}, e_{h}\right]$ respectively. $\left(q_{l}, q_{h}, s_{l}, s_{h}\right.$ 
and $e_{l}, e_{h}$ respectively represent the lower and upper limits of power quality, energy storage quality and carbon emissions). The probability density functions and the cumulative distribution functions are $f_{q}\left(q_{i}\right)$ and $F_{q}\left(q_{i}\right)$, $f_{s}\left(s_{i}\right)$ and $F_{s}\left(s_{i}\right), f_{e}\left(e_{i}\right)$ and $F_{e}\left(e_{i}\right)$ respectively.

Hypothesis 2. Carbon emissions $e_{i}$ are expressed as a decreasing function of utilization rate of renewable energy $r_{i}$ and comprehensive utilization rate of energy $o_{i}$.

From the previous analysis of the impact of carbon emissions, we find that as the micro-grid system enhances the utilization rate of renewable energy and clean energy, it will reduce the level of carbon emissions in the micro-grid system. When the comprehensive utilization rate of energy of the micro-grid system increases, the efficiency of clean energy increases, and the consumption of energy for external carbon emissions is reduced, the level of carbon emissions from micro-grid systems will also be reduced. These two aspects are important to carbon emissions, so this assumption is reasonable.

Hypothesis 3. The bidding price of energy supplier is a function of power quality, energy storage quality and carbon emissions, which are private information of the energy supplier. That is, energy suppliers only know their own tender's $p_{i}, q_{i}, s_{i}$ and $e_{i}$, and the distribution function of other energy suppliers, but don't know the specific bidding value of other energy suppliers.

Hypothesis 4. The risk preference of the project owner and the energy supplier is neutral and both are rational economic persons, making decisions on the basis of perfect and complete information.

The return function of micro-grid project owner is a linear function about quality attributes, value coefficient and the bidding price, expressed as:

$$
\mathrm{U}\left(\mathrm{p}_{\mathrm{i}}, \mathrm{q}_{\mathrm{i}}, \mathrm{v}_{\mathrm{s}}, \mathrm{e}_{\mathrm{i}}\right)=\mathrm{v}_{\mathrm{q}} \mathrm{q}_{\mathrm{i}}+\mathrm{v}_{\mathrm{s}} \mathrm{s}_{\mathrm{i}}+\mathrm{v}_{\mathrm{e}}\left(\mathrm{E}-\mathrm{e}_{\mathrm{i}}\right)-\mathrm{p}_{\mathrm{i}}
$$

The return function of micro-grid energy supplier is a linear function about bidding price, quality attributes and cost coefficient, expressed as:

$$
\pi_{i}\left(p_{i}, q_{i}, e_{i}\right)=p_{i}-c_{q} q_{i}-c_{s} s_{i}-c_{e}\left(E-e_{i}\right)
$$

During the bidding, the probability micro-grid energy supplier wins the bidding affected by supplier number $n$, the bidding price of $\mathrm{p}_{\mathrm{i}}$, power quality $\mathrm{q}_{\mathrm{i}}$, energy storage quality $\mathrm{s}_{\mathrm{i}}$, and carbon emissions of $\mathrm{e}_{\mathrm{i}}$. At the same time, when micro-grid energy supplier wins the auction, the benefits of project owner should be optimal. This probability is recorded as prob $\left(\mathrm{p}_{\mathrm{i}}, \mathrm{q}_{\mathrm{i}}, \mathrm{s}_{\mathrm{i}}, \mathrm{e}_{\mathrm{i}}, \mathrm{U}^{*}, \mathrm{n}\right)$, abbreviated as prob(.). Thus, the expected return that energy supplier winning bid can be expressed as:

$$
\mathrm{E}\left(\pi_{\mathrm{i}}\right)=\left[\mathrm{p}_{\mathrm{i}}-\mathrm{c}_{\mathrm{q}} \mathrm{q}_{\mathrm{i}}-\mathrm{c}_{\mathrm{s}} \mathrm{s}_{\mathrm{i}}-\mathrm{c}_{\mathrm{e}}\left(\mathrm{E}-\mathrm{e}_{\mathrm{i}}\right)\right] * \operatorname{prob}(.)-\mathrm{C}_{\mathrm{f}}
$$

Hypothesis 5. We can differentiate the technology type $t_{i}$ of energy supplier $i(i=1 \ldots n)$ with power quality, energy storage quality and carbon emissions of the energy supplier's bidding. In the meantime, the judgment function of project owner on the type of energy supplier is:

$$
\mathrm{t}_{\mathrm{i}}=\left(\mathrm{v}_{\mathrm{q}}-\mathrm{c}_{\mathrm{q}}\right) \mathrm{q}_{\mathrm{i}}+\left(\mathrm{v}_{\mathrm{s}}-\mathrm{c}_{\mathrm{s}}\right) \mathrm{s}_{\mathrm{i}}+\left(\mathrm{v}_{\mathrm{e}}-\mathrm{c}_{\mathrm{e}}\right)\left(\mathrm{E}-\mathrm{e}_{\mathrm{i}}\right)
$$

Since $\left(v_{q}-c_{q}\right)$ represents the marginal revenue of the unit power quality, $\left(v_{s}-c_{s}\right)$, represents the marginal revenue of the unit energy storage capacity, $\left(v_{e}-c_{e}\right)$, represents the marginal revenue of the unit carbon emissions, so it is reasonable to distinguish the type of energy supplier use the formula above. Calculating cumulative distribution function of $\mathrm{t}_{\mathrm{i}}$. Making $\mathrm{q}_{\mathrm{i}}^{\prime}=\left(\mathrm{v}_{\mathrm{q}}-\mathrm{c}_{\mathrm{q}}\right) \mathrm{q}_{\mathrm{i}}, \mathrm{s}_{\mathrm{i}}^{\prime}=\left(\mathrm{v}_{\mathrm{s}}-\mathrm{c}_{\mathrm{s}}\right) \mathrm{s}_{\mathrm{i}}$, $\mathrm{e}_{\mathrm{i}}^{\prime}=\left(\mathrm{v}_{\mathrm{e}}-\mathrm{c}_{\mathrm{e}}\right)\left(\mathrm{E}-\mathrm{e}_{\mathrm{i}}\right)$. After transformation, $\mathrm{t}_{\mathrm{i}}=\mathrm{q}_{\mathrm{i}}^{\prime}+\mathrm{s}_{\mathrm{i}}^{\prime}+\mathrm{e}_{\mathrm{i}}^{\prime}$. From Hypothesis 1 we know $\mathrm{q}_{\mathrm{i}}, \mathrm{s}_{\mathrm{i}}$ and 
$e_{i}$ independent of each other, so $\mathrm{q}_{i}^{\prime}, s_{i}^{\prime}$ and $e_{i}^{\prime}$ also independent of each other. Moreover, since $\mathrm{q}_{i}^{\prime}$ is a linear relationship of $\mathrm{q}_{\mathrm{i}}$, the density function $\mathrm{f}_{\mathrm{q}_{\mathrm{i}}^{\prime}}\left(\mathrm{q}_{\mathrm{i}}^{\prime}\right)$ of $\mathrm{q}_{\mathrm{i}}^{\prime}$ is also a linear transformation of $\mathrm{f}_{\mathrm{q}}\left(\mathrm{q}_{\mathrm{i}}\right)$. Similarly, $\mathrm{f}_{\mathrm{s}_{\mathrm{i}}}\left(\mathrm{s}_{\mathrm{i}}^{\prime}\right), \mathrm{f}_{\mathrm{e}_{\mathrm{i}}^{\prime}}\left(\mathrm{e}_{\mathrm{i}}^{\prime}\right)$ are also a linear transformation of $\mathrm{f}_{\mathrm{s}}\left(\mathrm{s}_{\mathrm{i}}\right)$, and $\mathrm{f}_{\mathrm{e}}\left(\mathrm{e}_{\mathrm{i}}\right)$, respectively. As $\mathrm{f}_{\mathrm{q}}\left(\mathrm{q}_{\mathrm{i}}\right)$, $\mathrm{f}_{\mathrm{s}}\left(\mathrm{s}_{\mathrm{i}}\right)$, and $\mathrm{f}_{\mathrm{e}}\left(\mathrm{e}_{\mathrm{i}}\right)$ are known, so $\mathrm{f}_{\mathrm{q}_{\mathrm{i}}^{\prime}}\left(\mathrm{q}_{\mathrm{i}}^{\prime}\right), \mathrm{f}_{\mathrm{s}_{\mathrm{i}}^{\prime}}\left(\mathrm{s}_{\mathrm{i}}^{\prime}\right)$, and $\mathrm{f}_{\mathrm{e}_{\mathrm{i}}^{\prime}}\left(\mathrm{e}_{\mathrm{i}}^{\prime}\right)$ also are known. The cumulative distribution function of the energy supplier type can be calculated by the multiple convolution calculation method and the boundary relation of $t_{i}$ :

$$
\begin{aligned}
& \mathrm{F}_{\mathrm{t}}\left(\mathrm{t}_{\mathrm{i}}\right)=\int_{\mathrm{t}_{1}}^{\mathrm{t}_{\mathrm{i}}} \mathrm{f}_{\mathrm{t}}(\mathrm{t}) \mathrm{dt}=\int_{\mathrm{t}_{1}}^{\mathrm{t}_{\mathrm{i}}}\left[\mathrm{f}_{\mathrm{q}_{\mathrm{i}}^{\prime}}\left(\mathrm{q}_{\mathrm{i}}^{\prime}\right) \mathrm{f}_{\mathrm{s}_{\mathrm{i}}^{\prime}}\left(\mathrm{s}_{\mathrm{i}}^{\prime}\right) \mathrm{f}_{\mathrm{e}_{\mathrm{i}}^{\prime}}\left(\mathrm{e}_{\mathrm{i}}^{\prime}\right)\right] \mathrm{dt}=\int_{\mathrm{t}_{1}}^{\mathrm{t}_{\mathrm{i}}}\left[\int_{-\infty}^{+\infty} \int_{-\infty}^{+\infty} \mathrm{f}_{\mathrm{q}_{\mathrm{i}}^{\prime}}\left(\mathrm{x}_{1}\right) \mathrm{f}_{\mathrm{s}_{\mathrm{i}}^{\prime}}\left(\mathrm{x}_{2}\right) \mathrm{f}_{\mathrm{e}_{\mathrm{i}}^{\prime}}\left(\mathrm{t}-\mathrm{x}_{1}-\mathrm{x}_{2}\right) \mathrm{dx_{2 }} d \mathrm{x}_{1}\right] \mathrm{dt} \\
& =\int_{\mathrm{t}_{1}}^{\mathrm{t}_{\mathrm{i}}}\left[\int_{\mathrm{t}_{1}}^{\mathrm{t}}\left[\int_{\mathrm{t}_{1}}^{\mathrm{t}-\mathrm{x}_{1}} \mathrm{f}_{\mathrm{q}_{\mathrm{i}}^{\prime}}\left(\mathrm{x}_{1}\right) \mathrm{f}_{\mathrm{s}_{\mathrm{i}}^{\prime}}\left(\mathrm{x}_{2}\right) \mathrm{f}_{\mathrm{e}_{\mathrm{i}}^{\prime}}\left(\mathrm{t}-\mathrm{x}_{1}-\mathrm{x}_{2}\right) d \mathrm{x}_{2}\right] \mathrm{d} \mathrm{x}_{1}\right] \mathrm{dt},
\end{aligned}
$$

$t_{1}$ is the lower limit of $t_{i}, t_{l}=\left(v_{q}-c_{q}\right) q_{1}+\left(v_{s}-c_{s}\right) s_{1}+\left(v_{e}-c_{e}\right)\left(E-e_{h}\right)$. The density function and the value of the above equation are known, so $F_{t}\left(t_{i}\right)$ is known.

Hypothesis 6 . There is no conspiracy between the energy suppliers in bidding. The bidding of energy supplier is determined according to the bidding function $B$, and $B$ is an increasing function.

That is, when the energy supplier $i(i=1 \ldots n)$ 's multi-attribute bidding vector is $\mathrm{U}_{\mathrm{i}}=\left(\mathrm{p}_{\mathrm{i}}, \mathrm{q}_{\mathrm{i}}, \mathrm{s}_{\mathrm{i}}, \mathrm{e}_{\mathrm{i}}\right)$, then $\mathrm{i}$ will bid for $\mathrm{B}\left(\mathrm{U}_{\mathrm{i}}\right)$. Meanwhile, since both $\mathrm{p}_{\mathrm{i}}=\left(\mathrm{q}_{\mathrm{i}}, \mathrm{s}_{\mathrm{i}}, \mathrm{e}_{\mathrm{i}}\right)$ and $\mathrm{t}_{\mathrm{i}}=\left(\mathrm{q}_{\mathrm{i}}, \mathrm{s}_{\mathrm{i}}, \mathrm{e}_{\mathrm{i}}\right)$ are the increasing functions of $q_{i}, s_{i}$ and $e_{i}$. Namely, when the bidding price $p_{i}$ is higher, that means the type of energy supplier $t_{i}$ is better, so $B$ is also an increasing function.

During the bidding, in order to obtain the franchise, energy suppliers may be in collusion with each other, which will not only improve the winning price, but also reduce the quality of the project and damage the interests of project owners. In order to avoid this situation, project owners will usually take measures to prevent the bidder conspiracy. So, the assumption that there is no conspiracy is reasonable.

\subsection{Game Analysis of Auction Mechanism}

First, we use inverse method to analyze the optimal strategy. By Hypothesis 4, the project owner and the energy supplier make decisions on the basis of perfect, complete information. Therefore, at the Nash equilibrium of the third stage of auction, the project owners will choose energy suppliers who bring them the maximum benefits as the bid winner. At this point, the project owner's return and energy supplier's bid satisfies the following equation:

$$
\mathrm{U}_{\mathrm{i}}=\mathrm{v}_{\mathrm{q}} \mathrm{q}_{\mathrm{i}}+\mathrm{v}_{\mathrm{s}} \mathrm{s}_{\mathrm{i}}+\mathrm{v}_{\mathrm{e}}\left(\mathrm{E}-\mathrm{e}_{\mathrm{i}}\right)-\mathrm{p}_{\mathrm{i}}=\operatorname{Max}_{\mathrm{j}}(\mathrm{j}=1 \ldots \mathrm{n}),
$$

Reverse to the second stage, when the energy supplier bidding, energy supplier will bid according to their own type and the tender vector, which can maximize their interests. Thus, when energy supplier wins the auction in the third stage, the type of energy supplier, the bid vector, and the return satisfy the following equation:

$$
\operatorname{Max} \pi_{\mathrm{i}}\left(\mathrm{t}_{\mathrm{i}}, \mathrm{U}_{\mathrm{i}}\right)=\left(\mathrm{t}_{\mathrm{i}}-\mathrm{U}_{\mathrm{i}}\right) * \operatorname{prob}\left(\mathrm{p}_{\mathrm{i}}, \mathrm{q}_{\mathrm{i}}, \mathrm{s}_{\mathrm{i}}, \mathrm{e}_{\mathrm{i}}, \mathrm{U}^{*}, \mathrm{n}\right)-\mathrm{C}_{\mathrm{f}},
$$

According to optimization theory, the Nash equilibrium is solved for the above formula, and the optimal price of the energy supplier is deduced as follows:

Theorem 1. In the auction of micro-grid project transfer, the optimal bidding price for the energy supplier to participate in the auction is:

$$
p_{i}= \begin{cases}\text { Not to participate in the bidding, } & t_{i}<t_{m} \\ v_{q} q_{i}+v_{s} s_{i}+v_{e}\left(E-e_{i}\right), & t_{i}=t_{m} \\ c_{q} q_{i}+c_{s} s_{i}+c_{e}\left(E-e_{i}\right)+\frac{\int_{t_{m}}^{t_{i}}\left(F_{t}(t)\right)^{n-1} d t}{\left(F_{t}\left(t_{i}\right)\right)^{n-1}}+\frac{C_{f}}{\left(F_{t}\left(t_{i}\right)\right)^{n-1},} & t_{i}>t_{m}\end{cases}
$$


$t_{m}=\left(q_{m}, s_{m}, e_{m}\right)$ is the type of energy supplier when bidding reaches Nash equilibrium.

Proof. When the energy supplier I 's bid is a Nash equilibrium, the returns of project owner $\mathrm{E}\left(\pi_{\mathrm{i}}\right)$ and the energy supplier $\mathrm{U}_{\mathrm{m}}$ are both 0 . That is $\mathrm{E}\left(\pi_{\mathrm{m}}\right)=\left(\mathrm{t}_{\mathrm{m}}-\mathrm{U}_{\mathrm{m}}\right) * \operatorname{prob}\left(\mathrm{p}_{\mathrm{i}}, \mathrm{q}_{\mathrm{i}}, \mathrm{e}_{\mathrm{i}}, \mathrm{U}^{*}, \mathrm{n}\right)-\mathrm{c}_{\mathrm{f}}=\mathrm{t}_{\mathrm{m}} *$ $\operatorname{prob}()-.c_{\mathrm{f}}=0$. The probability $\operatorname{prob}($.$) that energy supplier win the auction is equal to the probability$ when other energy suppliers' type is less than equilibrium type, namely, $\operatorname{prob}()=.\mathrm{F}_{\mathrm{t}}\left(\mathrm{t}_{\mathrm{m}}\right)^{\mathrm{n}-1}$. Therefore, the returns of energy suppliers can be written as $\mathrm{E}\left(\pi_{\mathrm{m}}\right)=\mathrm{t}_{\mathrm{m}} \mathrm{F}_{\mathrm{t}}\left(\mathrm{t}_{\mathrm{m}}\right)^{\mathrm{n}-1}-\mathrm{C}_{\mathrm{f}}$.

When $t_{i}<t_{m}$, since $t_{i}<t_{m}, C_{f}>0$, and $F_{t}\left(t_{i}\right)$ are increasing functions, the expected return of the energy supplier $E\left(\pi_{i}\right)=t_{i} F_{t}\left(t_{i}\right)^{n-1}-C_{f}<t_{m} F_{t}\left(t_{m}\right)^{n-1}-C_{f}<0$ are available. At this point, the expected return of energy supplier is less than the bid cost, thus the energy supplier's best strategy is not to participate in the bidding. At this time, because the power quality, energy storage quality, and carbon emissions provided by energy supplier cannot meet the requirements of project owner at the same time. Even if energy suppliers participate in the bidding, they will not win the bid, only to waste the bid cost, $\mathrm{C}_{\mathrm{f}}$.

When $t_{i}=t_{m}$, the energy supplier's bid vector is located at the Nash equilibrium, where the costs of the energy supplier are equal to the benefits. At this point, the project owner's returns are 0 , the following formula is satisfied:

$$
\mathrm{U}_{\mathrm{i}}\left(\mathrm{p}_{\mathrm{i}}, \mathrm{q}_{\mathrm{i}}, \mathrm{e}_{\mathrm{i}}\right)=\mathrm{v}_{\mathrm{q}} \mathrm{q}_{\mathrm{i}}+\mathrm{v}_{\mathrm{s}} \mathrm{s}_{\mathrm{i}}+\mathrm{v}_{\mathrm{e}}\left(\mathrm{E}-\mathrm{e}_{\mathrm{i}}\right)-\mathrm{p}_{\mathrm{i}}=0,
$$

Equation (8) transformation, the tender price of energy supplier is:

$$
\mathrm{p}_{\mathrm{i}}=\mathrm{v}_{\mathrm{q}} \mathrm{q}_{\mathrm{i}}+\mathrm{v}_{\mathrm{s}} \mathrm{s}_{\mathrm{i}}+\mathrm{v}_{\mathrm{e}}\left(\mathrm{E}-\mathrm{e}_{\mathrm{i}}\right)=\mathrm{v}_{\mathrm{q}} \mathrm{q}_{\mathrm{m}}+\mathrm{v}_{\mathrm{s}} \mathrm{s}_{\mathrm{m}}+\mathrm{v}_{\mathrm{e}}\left(\mathrm{E}-\mathrm{e}_{\mathrm{m}}\right),
$$

When $t_{i}>t_{m}$, assuming $i$ is the winner of the tender, the bid vector $U_{i}=\left(p_{i}, q_{i}, s_{i}, e_{i}\right)$ is satisfied $B\left(U_{j}\right)<B\left(U_{i}\right), j(j=1 \ldots n) \neq i$, the probability of winning the bid is $\operatorname{prob}\left(B\left(U_{i}\right)\right)=$ $\left[\mathrm{F}_{\mathrm{t}}\left(\mathrm{B}^{-1}\left(\mathrm{U}_{\mathrm{i}}\right)\right)\right]^{\mathrm{n}-1}$, and the returns of $\mathrm{i}$ can be written as $\pi_{\mathrm{i}}\left(\mathrm{t}_{\mathrm{i}}, \mathrm{U}_{\mathrm{i}}\right)=\left(\mathrm{t}_{\mathrm{i}}-\mathrm{U}_{\mathrm{i}}\right) *\left[\mathrm{~F}_{\mathrm{t}}\left(\mathrm{B}^{-1}\left(\mathrm{U}_{\mathrm{i}}\right)\right)\right]^{\mathrm{n}-1}-\mathrm{C}_{\mathrm{f}}$.

At this time, the energy supplier's bid must be the best bid $U_{i}^{*}$, therefore:

$$
\left.\frac{\partial \pi_{\mathrm{i}}}{\partial \mathrm{U}_{\mathrm{i}}}\right|_{\mathrm{U}_{\mathrm{i}}=\mathrm{U}_{\mathrm{i}}^{*}}=0
$$

Take the derivative of $\pi_{i}\left(t_{i}, U_{i}\right)$ with respect to $t_{i}$, we get:

$$
\frac{d \pi_{i}}{d t_{i}}=\frac{\partial \pi_{i}}{\partial t_{i}}+\frac{\partial \pi_{i}}{\partial U_{i}} \frac{d U_{i}}{d t_{i}}
$$

From the above two equations and the meaning of partial derivative, we get:

$$
\left.\frac{\mathrm{d} \pi_{\mathrm{i}}}{\mathrm{dt} \mathrm{t}_{\mathrm{i}}}\right|_{\mathrm{U}_{\mathrm{i}}=\mathrm{U}_{\mathrm{i}}^{*}}=\left.\frac{\partial \pi_{\mathrm{i}}}{\partial \mathrm{t}_{\mathrm{i}}}\right|_{\mathrm{U}_{\mathrm{i}}=\mathrm{U}_{\mathrm{i}}^{*}}+\left.\frac{\partial \pi_{\mathrm{i}}}{\partial \mathrm{U}_{\mathrm{i}}}\right|_{\mathrm{U}_{\mathrm{i}}=\mathrm{U}_{\mathrm{i}}^{*}} \frac{\mathrm{dU_{ \textrm {i } }}}{\mathrm{dt} \mathrm{t}_{\mathrm{i}}}=\left.\frac{\partial \pi_{\mathrm{i}}}{\partial \mathrm{t}_{\mathrm{i}}}\right|_{\mathrm{U}_{\mathrm{i}}=\mathrm{U}_{\mathrm{i}}^{*}}=\left[\mathrm{F}_{\mathrm{t}}\left(\mathrm{B}^{-1}\left(\mathrm{U}_{\mathrm{i}}\right)\right)\right]^{\mathrm{n}-1},
$$

By Hypothesis 1, at equilibrium, the same type of energy supplier has equal bid strategy, namely, $\mathrm{U}_{\mathrm{i}}=\mathrm{B}\left(\mathrm{t}_{\mathrm{i}}\right)$. So,

$$
\frac{\mathrm{d} \pi_{\mathrm{i}}}{\mathrm{dt}_{\mathrm{i}}}=\left(\mathrm{F}_{\mathrm{t}}\left(\mathrm{t}_{\mathrm{i}}\right)\right)^{\mathrm{n}-1}
$$

By calculating the integral of Equation (13), we have:

$$
\pi_{\mathrm{i}}-\pi_{\mathrm{i}}\left(\mathrm{t}_{\mathrm{m}}\right)=\int_{\mathrm{t}_{\mathrm{m}}}^{\mathrm{t}_{\mathrm{i}}}\left(\mathrm{F}_{\mathrm{t}}(\mathrm{t})\right)^{\mathrm{n}-1} d \mathrm{t},
$$

By equilibrium $\pi_{\mathbf{i}}\left(t_{m}\right)=0$, we obtain: 


$$
\pi_{\mathrm{i}}=\int_{\mathrm{t}_{\mathrm{m}}}^{\mathrm{t}_{\mathrm{i}}}\left(\mathrm{F}_{\mathrm{t}}(\mathrm{t})\right)^{\mathrm{n}-1} \mathrm{dt},
$$

The above formula combined with $\pi_{i}\left(t_{i}, U_{i}\right)=\left(t_{i}-U_{i}\right) F_{t}\left(t_{i}\right)^{n-1}-C_{f}$, we obtain:

$$
p_{i}=c_{q} q_{i}+c_{s} s_{i}+c_{e}\left(E-e_{i}\right)+\frac{\int_{t_{m}}^{t_{i}}\left(F_{t}(t)\right)^{n-1} d t}{\left(F_{t}\left(t_{i}\right)\right)^{n-1}}+\frac{C_{f}}{\left(F_{t}\left(t_{i}\right)\right)^{n-1}},
$$

Theorem 1 is proved. From the Theorem 1, when the type of energy supplier is less than or equal to the type of equilibrium, the optimal strategy of energy supplier is not to participate in the bidding. Because when less than or equal to the type of equilibrium, energy supplier participates in bidding not only the expected return of bidding is 0 , but also loss of bidding costs. Only when the type of energy supplier is greater than the equilibrium type, it is advisable for energy supplier to participate in bidding. At this point, the energy supplier's expected return will be greater than the cost. At the same time, by calculating we can see that the bidding price is the Nash equilibrium value.

Theorem 2. At the sub-game Nash equilibrium point of micro-grid project auction, with the improvement of requirement by project owner for utilization rate of renewable energy and comprehensive utilization rate of energy, the type of energy supplier will also increase at equilibrium.

Proof. Equilibrium equations are:

$$
\mathrm{t}_{\mathrm{m}}=\left(\mathrm{v}_{\mathrm{q}}-\mathrm{c}_{\mathrm{q}}\right) \mathrm{q}_{\mathrm{m}}+\left(\mathrm{v}_{\mathrm{s}}-\mathrm{c}_{\mathrm{s}}\right) \mathrm{s}_{\mathrm{m}}+\left(\mathrm{v}_{\mathrm{e}}-\mathrm{c}_{\mathrm{e}}\right)\left(\mathrm{E}-\mathrm{e}_{\mathrm{m}}\right),
$$

From the Hypothesis 1, carbon emission $e_{i}$ is the reduction function of the utilization rate of renewable energy $r_{i}$ and comprehensive utilization rate of energy $o_{i}$, set the expression is $e_{i}(r, o)=$ $1-\left(\mathrm{w}_{\mathrm{r}} \mathrm{r}_{\mathrm{i}}+\mathrm{w}_{\mathrm{o}} \mathrm{O}_{\mathrm{i}}\right), \mathrm{w}_{\mathrm{r}}$ and $\mathrm{w}_{\mathrm{o}}$ arethe relevant weight coefficient respectively.

When $v_{e}$ and $c_{e}$ remain unchanged, the difference between the new equilibrium and the equilibrium is:

$$
\mathrm{t}_{\mathrm{m}}^{\prime}-\mathrm{t}_{\mathrm{m}}=\left(\mathrm{v}_{\mathrm{e}}-\mathrm{c}_{\mathrm{e}}\right)\left(\mathrm{e}_{\mathrm{m}}-\mathrm{e}_{\mathrm{m}}^{\prime}\right),
$$

By the Hypothesis 2, the above equation is positive, so the equilibrium level rises.

When $v_{e}$ and $c_{e}$ changed, we assume that when the utilization rate of renewable energy and comprehensive utilization rate of energy increase, carbon emission value coefficient and cost coefficient will increase corresponding. The new equilibrium equation is:

$$
\mathrm{t}_{\mathrm{m}}^{\prime}=\left(\mathrm{v}_{\mathrm{q}}-\mathrm{c}_{\mathrm{q}}\right) \mathrm{q}_{\mathrm{m}}+\left(\mathrm{v}_{\mathrm{s}}-\mathrm{c}_{\mathrm{s}}\right) \mathrm{s}_{\mathrm{m}}+\left(\mathrm{v}_{\mathrm{e}}^{\prime}-\mathrm{c}_{\mathrm{e}}^{\prime}\right)\left(\mathrm{E}-\mathrm{e}_{\mathrm{m}}^{\prime}\right),
$$

We use the increment to represent the new equilibrium value:

$$
\begin{gathered}
\mathrm{e}_{\mathrm{m}}^{\prime}=\mathrm{e}_{\mathrm{m}}+\Delta_{\mathrm{e}}, \\
\mathrm{v}_{\mathrm{e}}^{\prime}=\mathrm{v}_{\mathrm{e}}+\Delta_{\mathrm{v}}, \\
\mathrm{c}_{\mathrm{e}}^{\prime}=\mathrm{c}_{\mathrm{e}}+\Delta_{\mathrm{c}},
\end{gathered}
$$

$\mathrm{s}_{\mathrm{m}}^{\prime}, \mathrm{v}_{\mathrm{s}}^{\prime}, \mathrm{c}_{\mathrm{s}}^{\prime}$ and $\Delta_{\mathrm{s}}, \Delta_{\mathrm{v}}, \Delta_{\mathrm{c}}$ represent the new andincremental valuesof $\mathrm{s}_{\mathrm{m}}, \mathrm{v}_{\mathrm{s}}$ and $\mathrm{c}_{\mathrm{s}}$ respectively. By substituting the incremental formula in the following calculation, we attain:

$$
\begin{gathered}
\mathrm{t}_{\mathrm{m}}^{\prime}-\mathrm{t}_{\mathrm{m}}=\left(\mathrm{v}_{\mathrm{e}}^{\prime}-\mathrm{c}_{\mathrm{e}}^{\prime}\right)\left(\mathrm{E}-\mathrm{e}_{\mathrm{m}}^{\prime}\right)-\left(\mathrm{v}_{\mathrm{e}}-\mathrm{c}_{\mathrm{e}}\right)\left(\mathrm{E}-\mathrm{e}_{\mathrm{m}}\right)=\left(\mathrm{v}_{\mathrm{e}}+\Delta_{\mathrm{v}}-\left(\mathrm{c}_{\mathrm{e}}+\Delta_{\mathrm{c}}\right)\right)\left(\mathrm{E}-\mathrm{e}_{\mathrm{m}}-\Delta_{\mathrm{e}}\right)- \\
\left(\mathrm{v}_{\mathrm{e}}-\mathrm{c}_{\mathrm{e}}\right)\left(\mathrm{E}-\mathrm{e}_{\mathrm{m}}\right)=\left(\mathrm{v}_{\mathrm{e}}^{\prime}-\mathrm{c}_{\mathrm{e}}^{\prime}\right) \Delta_{\mathrm{s}}+\left(\Delta_{\mathrm{v}}-\Delta_{\mathrm{c}}\right)\left(\mathrm{E}-\mathrm{e}_{\mathrm{m}}\right)>0,
\end{gathered}
$$


Theorem 2 is proved. In the case of proportional growth, the increment of $\mathrm{v}_{\mathrm{e}}$ is greater than the increment of $c_{e}$ due to $v_{e}$ significant greater than $c_{e}$. When the growth rate of the value coefficient is greater than the growth of the cost coefficient, the increase rate of the equilibrium level will be further improved. By Theorem 2, when the requirement of project owner for utilization rate of renewable energy and comprehensive utilization rate of energy are improved, the type of energy supplier will also increase when it is balanced. According to Theorem 4, with an improvement of type of energy supplier, the quality of micro-grid project and the satisfaction of project owner's demand will be improved, which will help to improve the benefits of project owner. To sum up, the project owner in the auction can hint his preference for utilization rate of renewable energy and comprehensive utilization rate to control the auction quality of micro-grid projects, and enhance the value of micro-grid projects and their own benefits. This is reasonable. The government is also through these two factors to control the quality of micro-grid development in reality [1].The inspiration for energy supplier is that energy supplier can innovate the mechanism of utilization of renewable energy, and innovate method of the comprehensive utilization of various energy sources to enhance their type to win the auction.

Theorem 3. At the sub-game Nash equilibrium point of micro-grid project auction, with the increase of pre-bid costs and the number of energy suppliers participating in the bidding, the type of energy supplier will also increase at equilibrium.

Proof. The return function of equilibrium is:

$$
\pi_{\mathrm{i}}\left(\mathrm{t}_{\mathrm{m}}\right)=\mathrm{t}_{\mathrm{m}} \mathrm{F}_{\mathrm{t}}\left(\mathrm{t}_{\mathrm{m}}\right)^{\mathrm{n}-1}-\mathrm{C}_{\mathrm{f}}=0,
$$

Transform the equation, and we get:

$$
\mathrm{t}_{\mathrm{m}} \mathrm{F}_{\mathrm{t}}\left(\mathrm{t}_{\mathrm{m}}\right)^{\mathrm{n}-1}=\mathrm{C}_{\mathrm{f}}
$$

Since both $t_{m}$ and $F_{t}\left(t_{m}\right)$ are increasing functions, $t_{m}$ will increase as the bidding $\operatorname{cost} C_{f}$ increases. Since $0 \leq F_{t}\left(t_{m}\right) \leq 1$, when $C_{f}$ does not change, $n$ increases, $t_{m}$ increases too. Theorem 3 is proved.

By Theorem 3, as a sinking cost, the pre-bid costs reflect pre-preparation for the auction of micro-grid project, and its level represents the degree of preliminary work of energy supplier. With the rise in pre-bid costs, the type of energy supplier will improve, that is, more excellent energy suppliers will join the auction of micro-grid project. When $C_{f}=0, t_{m}=0$, that is, the lower type of energy supplier can participate in auction, which reduces the auction quality of micro-grid project, and is detrimental to the interests of project owners. When the number of energy suppliers participating in the auction increases, the competition for micro-grid project auctions will increase, and the type of energy suppliers will increase when it is balanced, which will increase the returns of project owners. In summary, the project owner can design the corresponding mechanism before the auction to control the cost of pre-bidding and the number of energy suppliers to control the auction quality of the micro-grid project.

Theorem 4. In the auction of micro-grid project transfer, when energy suppliers bid at the optimal price, with the type of energy supplier increase, the returns of project owner and energy supplier also improve at equilibrium.

Proof. When $t_{i}<t_{m}$, energy supplier does not participate in the auction. When $t_{i}=t_{m}$, the return of energy supplier participation in the auction is 0 . So, we consider the situation of $t_{i}>t_{m}$.

Project owner:

$$
\begin{gathered}
\mathrm{U}_{\mathrm{i}}\left(\mathrm{p}_{\mathrm{i}}, \mathrm{q}_{\mathrm{i}}, \mathrm{s}_{\mathrm{i}}, \mathrm{e}_{\mathrm{i}}\right)=\mathrm{v}_{\mathrm{q}} \mathrm{q}_{\mathrm{i}}+\mathrm{v}_{\mathrm{s}} \mathrm{s}_{\mathrm{i}}+\mathrm{v}_{\mathrm{e}}\left(\mathrm{E}-\mathrm{e}_{\mathrm{i}}\right)-\mathrm{p}_{\mathrm{i}} \\
\mathrm{p}_{\mathrm{i}}=\mathrm{c}_{\mathrm{q}} \mathrm{q}_{\mathrm{i}}+\mathrm{c}_{\mathrm{s}} \mathrm{s}_{\mathrm{i}}+\mathrm{c}_{\mathrm{e}}\left(\mathrm{E}-\mathrm{e}_{\mathrm{i}}\right)+\frac{\int_{\mathrm{t}_{\mathrm{m}}}^{\mathrm{t}_{\mathrm{t}}}\left(\mathrm{F}_{\mathrm{t}}(\mathrm{t})\right)^{\mathrm{n}-1} \mathrm{dt}}{\left(\mathrm{F}_{\mathrm{t}}\left(\mathrm{t}_{\mathrm{i}}\right)\right)^{\mathrm{n}-1}}+\frac{\mathrm{C}_{\mathrm{f}}}{\left(\mathrm{F}_{\mathrm{t}}\left(\mathrm{t}_{\mathrm{i}}\right)\right)^{\mathrm{n}-1}},
\end{gathered}
$$


By substituting Equation (27) in Equation (26), we get the Equation (28).

$$
\mathrm{U}_{\mathrm{i}}\left(\mathrm{p}_{\mathrm{i}}, \mathrm{q}_{\mathrm{i}}, \mathrm{e}_{\mathrm{i}}\right)=\mathrm{v}_{\mathrm{q}} \mathrm{q}_{\mathrm{i}}+\mathrm{v}_{\mathrm{s}} \mathrm{s}_{\mathrm{i}}+\mathrm{v}_{\mathrm{e}}\left(\mathrm{E}-\mathrm{e}_{\mathrm{i}}\right)-\mathrm{p}_{\mathrm{i}}=\mathrm{t}_{\mathrm{i}}-\frac{\int_{\mathrm{t}_{\mathrm{m}}}^{\mathrm{t}_{\mathrm{i}}}\left(\mathrm{F}_{\mathrm{t}}(\mathrm{t})\right)^{\mathrm{n}-1} \mathrm{dt}}{\left(\mathrm{F}_{\mathrm{t}}\left(\mathrm{t}_{\mathrm{i}}\right)\right)^{\mathrm{n}-1}}-\frac{\mathrm{C}_{\mathrm{f}}}{\left(\mathrm{F}_{\mathrm{t}}\left(\mathrm{t}_{\mathrm{i}}\right)\right)^{\mathrm{n}-1}},
$$

Take the derivative of Equation (28) with respect to $t_{\mathrm{i}}$ :

$$
\begin{aligned}
& \frac{d U_{i}}{d t_{i}}=\frac{d}{d t_{i}}\left[t_{i}-\frac{\int_{t_{m}}^{t_{i}}\left(F_{t_{t}}\left(t_{i}\right)\right)^{n-1} d t}{\left(F_{t}\left(t_{i}\right)\right)^{n-1}}-\frac{C_{f}}{\left(F_{t}\left(t_{i}\right)\right)^{n-1}}\right]=\frac{d}{d t_{i}}\left[\frac{t_{i}\left(F_{t}\left(t_{i}\right)\right)^{n-1}-\int_{m}^{t_{i}}\left(F_{t}\left(t_{i}\right)\right)^{n-1} d t-C_{f}}{\left(F_{t}\left(t_{i}\right)\right)^{n-1}}\right]= \\
& \frac{\left(\mathrm{F}_{\mathrm{t}}\left(\mathrm{t}_{\mathrm{i}}\right)^{\mathrm{n}-1}+(\mathrm{n}-1) \mathrm{F}_{\mathrm{t}}\left(\mathrm{t}_{\mathrm{i}}\right)^{\mathrm{n}-2} \mathrm{~F}_{\mathrm{t}}^{\prime}\left(\mathrm{t}_{\mathrm{i}}\right)-\mathrm{F}_{\mathrm{t}}\left(\mathrm{t}_{\mathrm{i}}\right)^{\mathrm{n}-1}\right) \mathrm{F}_{\mathrm{t}}\left(\mathrm{t}_{\mathrm{i}}\right)^{\mathrm{n}-1}-\left(\mathrm{t}_{\mathrm{i}}\left(\mathrm{F}_{\mathrm{t}}\left(\mathrm{t}_{\mathrm{i}}\right)\right)^{\mathrm{n}-1}-\int_{\mathrm{t}_{\mathrm{m}}}^{\mathrm{t}_{\mathrm{i}}}\left(\mathrm{F}_{\mathrm{t}}\left(\mathrm{t}_{\mathrm{i}}\right)\right)^{\mathrm{n}-1} \mathrm{dt}-\mathrm{C}_{\mathrm{f}}\right)(\mathrm{n}-1) \mathrm{F}_{\mathrm{t}}\left(\mathrm{t}_{\mathrm{i}}\right)^{\mathrm{n}-2} \mathrm{~F}_{\mathrm{t}}{ }^{\prime}\left(\mathrm{t}_{\mathrm{i}}\right)}{\left.\left(\mathrm{F}_{\mathrm{t}}\left(\mathrm{t}_{\mathrm{i}}\right)^{\mathrm{n}-1}\right)^{2}\right)^{2}}= \\
& \frac{\left(\mathrm{t}_{\mathrm{i}}(\mathrm{n}-1) \mathrm{F}_{\mathrm{t}}\left(\mathrm{t}_{\mathrm{i}}\right)^{\mathrm{n}-2} \mathrm{~F}_{\mathrm{t}}^{\prime}\left(\mathrm{t}_{\mathrm{i}}\right)\right) \mathrm{F}_{\mathrm{t}}\left(\mathrm{t}_{\mathrm{i}}\right)^{\mathrm{n}-1}-\left(\mathrm{t}_{\mathrm{i}}\left(\mathrm{F}_{\mathrm{t}}\left(\mathrm{t}_{\mathrm{i}}\right)\right)^{\mathrm{n}-1}-\int_{\mathrm{t}_{\mathrm{m}}}^{\mathrm{t}_{\mathrm{i}}}\left(\mathrm{F}_{\mathrm{t}}\left(\mathrm{t}_{\mathrm{i}}\right)\right)^{\mathrm{n}-1} \mathrm{dt}-\mathrm{C}_{\mathrm{f}}\right)(\mathrm{n}-1) \mathrm{F}_{\mathrm{t}}\left(\mathrm{t}_{\mathrm{i}}\right)^{\mathrm{n}-2} \mathrm{~F}_{\mathrm{t}_{\mathrm{t}}^{\prime}}\left(\mathrm{t}_{\mathrm{i}}\right)}{\mathrm{F}_{\mathrm{t}}\left(\mathrm{t}_{\mathrm{i}}\right)^{\mathrm{n}}}= \\
& \frac{\left(\int_{t_{m}}^{t_{i}}\left(F_{t}(t)\right)^{n-1} d t+C_{f}\right)(n-1) F_{t}^{\prime}\left(t_{i}\right)}{\left(F_{t}\left(t_{i}\right)\right)^{n}}>0,
\end{aligned}
$$

Energy supplier:

$$
\mathrm{E}\left(\pi_{\mathrm{i}}\left(\mathrm{p}_{\mathrm{i}}, \mathrm{q}_{\mathrm{i}}, \mathrm{e}_{\mathrm{i}}\right)\right)=\left[\mathrm{p}_{\mathrm{i}}-\mathrm{c}_{\mathrm{q}} \mathrm{q}_{\mathrm{i}}-\mathrm{c}_{\mathrm{s}} \mathrm{s}_{\mathrm{i}}-\mathrm{c}_{\mathrm{e}}\left(\mathrm{E}-\mathrm{e}_{\mathrm{i}}\right)\right] * \operatorname{prob}(.)-\mathrm{c}_{\mathrm{f}},
$$

By substituting Equation (27) and equation $\operatorname{prob}()=.\left(\mathrm{F}_{\mathrm{t}}\left(\mathrm{t}_{\mathrm{i}}\right)\right)^{\mathrm{n}-1}$ in Equation (30), we get:

$$
\mathrm{E}\left(\pi_{\mathrm{i}}\left(\mathrm{p}_{\mathrm{i}}, \mathrm{q}_{\mathrm{i}}, \mathrm{s}_{\mathrm{i}}, \mathrm{e}_{\mathrm{i}}\right)\right)=\int_{\mathrm{t}_{\mathrm{m}}}^{\mathrm{t}_{\mathrm{i}}}\left(\mathrm{F}_{\mathrm{t}}\left(\mathrm{t}_{\mathrm{i}}\right)\right)^{\mathrm{n}-1} d \mathrm{t},
$$

Take the derivative of Equation (31) with respect to $t_{i}$ :

$$
\frac{\mathrm{d} \pi_{\mathrm{i}}}{\mathrm{dt}_{\mathrm{i}}}=\left(\mathrm{F}_{\mathrm{t}}\left(\mathrm{t}_{\mathrm{i}}\right)\right)^{\mathrm{n}-1}>0,
$$

Theorem 4 is proved. By Theorem 4, the project owner will pick the optimal type of energy supplier as the winner of the auction. We find that the equilibrium price is higher at this time since that $\mathrm{p}_{\mathrm{i}}$ and $\mathrm{t}_{\mathrm{i}}$ are an increasing function of $\left(\mathrm{q}_{\mathrm{i}}, \mathrm{s}_{\mathrm{i}}, \mathrm{e}_{\mathrm{i}}\right)$. In summary, the project owner will not choose the lowest price of energy suppliers as the winner of the tender, instead, he will choose excellent technical types, high prices of energy suppliers as the winner of the auction on the basis of a comprehensive consideration of the type and price of energy suppliers.

Theorem 5. In the auction of micro-grid project transfer, the optimal strategy for energy suppliers to participate in the auction is based on their real power quality, energy storage quality, carbon emissions and price, not affected by external returns, such as electricity price, government subsidies.

Proof. Assuming that other energy suppliers do not change, the energy supplier of type $t_{i}=\left(q_{i}, s_{i}, e_{i}\right)$ considers external returns, such as the electricity price, government subsidies, it will increase or decrease the type to $t_{i}^{\prime}=\left(q_{i}^{\prime}, s_{i}^{\prime}, e_{i}^{\prime}\right)$, then the energy supplier brings the returns $U_{i}^{\prime}$ to the project owner and the probability of winning the auction becomes $\left(\mathrm{F}_{t}\left(t_{i}^{\prime}\right)\right)^{n-1}$. That is, the type $t_{i}$ of energy supplier, by providing the type $t_{i}^{\prime}$ to bring the project owner returns $U_{i}^{\prime}$ to win the auction, then the probability that the energy supplier wins the auction is $\left(\mathrm{F}_{\mathrm{t}}\left(\mathrm{t}_{\mathrm{i}}^{\prime}\right)\right)^{\mathrm{n}-1}$. From $\pi_{\mathrm{i}}\left(\mathrm{t}_{\mathrm{i}}, \mathrm{U}_{\mathrm{i}}\right)=\left(\mathrm{t}_{\mathrm{i}}-\mathrm{U}_{\mathrm{i}}\left(\mathrm{t}_{\mathrm{i}}\right)\right) *\left(\mathrm{~F}_{\mathrm{t}}\left(\mathrm{t}_{\mathrm{i}}\right)\right)^{\mathrm{n}-1}-\mathrm{C}_{\mathrm{f}}$, the returns equation of energy supplier is:

$$
\pi_{\mathrm{i}}\left(\mathrm{t}_{\mathrm{i}}, \mathrm{t}_{\mathrm{i}}^{\prime}\right)=\left(\mathrm{t}_{\mathrm{i}}-\mathrm{U}_{\mathrm{i}}\left(\mathrm{t}_{\mathrm{i}}^{\prime}\right)\right) *\left(\mathrm{~F}_{\mathrm{t}}\left(\mathrm{t}_{\mathrm{i}}^{\prime}\right)\right)^{\mathrm{n}-1}-\mathrm{C}_{\mathrm{f}}=\mathrm{t}_{\mathrm{i}}\left(\mathrm{F}_{\mathrm{t}}\left(\mathrm{t}_{\mathrm{i}}^{\prime}\right)\right)^{\mathrm{n}-1}-\mathrm{U}_{\mathrm{i}}\left(\mathrm{t}_{\mathrm{i}}^{\prime}\right)\left(\mathrm{F}_{\mathrm{t}}\left(\mathrm{t}_{\mathrm{i}}^{\prime}\right)\right)^{\mathrm{n}-1}-\mathrm{C}_{\mathrm{f}},
$$

Take the partial derivative of Equation (33) with respect to $t_{i}^{\prime}$ : 


$$
\left.\frac{\partial \pi_{i}\left(t_{i}, t_{i}^{\prime}\right)}{\partial t_{i}^{\prime}}=t_{i} \frac{d}{d t_{i}^{\prime}}\left[F_{t}\left(t_{i}^{\prime}\right)\right)^{n-1}\right]-\frac{d}{d t_{i}^{\prime}}\left[U_{i}\left(t_{i}^{\prime}\right)\left(F_{t}\left(t_{i}^{\prime}\right)\right)^{n-1}\right],
$$

Let $\mathrm{U}_{\mathrm{i}}\left(\mathrm{t}_{\mathrm{i}}\right)\left(\mathrm{F}_{\mathrm{t}}\left(\mathrm{t}_{\mathrm{i}}\right)\right)^{\mathrm{n}-1}=\mathrm{K}_{\mathrm{i}}$, that is:

$$
K_{i}=U_{i}\left(t_{i}\right)\left(F_{t}\left(t_{i}\right)\right)^{n-1}=\left(v_{q} q_{i}+v_{s} s_{i}+v_{e}\left(E-e_{i}\right)-p_{i}\right)\left(F_{t}\left(t_{i}\right)\right)^{n-1},
$$

By substituting Equation (27) in Equation (35), we get:

$$
\begin{gathered}
\mathrm{K}_{\mathrm{i}}=\mathrm{U}_{\mathrm{i}}\left(\mathrm{t}_{\mathrm{i}}\right)\left(\mathrm{F}_{\mathrm{t}}\left(\mathrm{t}_{\mathrm{i}}\right)\right)^{\mathrm{n}-1}=\left(\mathrm{v}_{\mathrm{q}} \mathrm{q}_{\mathrm{i}}+\mathrm{v}_{\mathrm{s}} \mathrm{s}_{\mathrm{i}}+\mathrm{v}_{\mathrm{e}}\left(\mathrm{E}-\mathrm{e}_{\mathrm{i}}\right)-\mathrm{p}_{\mathrm{i}}\right)\left(\mathrm{F}_{\mathrm{t}}\left(\mathrm{t}_{\mathrm{i}}\right)\right)^{\mathrm{n}-1}= \\
\mathrm{t}_{\mathrm{i}}\left(\mathrm{F}_{\mathrm{t}}\left(\mathrm{t}_{\mathrm{i}}\right)\right)^{\mathrm{n}-1}-\int_{\mathrm{t}_{\mathrm{m}}}^{\mathrm{t}_{\mathrm{i}}}\left(\mathrm{F}_{\mathrm{t}}\left(\mathrm{t}_{\mathrm{i}}\right)\right)^{\mathrm{n}-1} \mathrm{dt}-\mathrm{C}_{\mathrm{f}},
\end{gathered}
$$

Take the derivative of Equation (36) with respect to $t_{i}$ :

$$
\left.\left.\frac{d K_{i}}{d t_{i}}=\left(F_{t}\left(t_{i}\right)\right)^{n-1}+t_{i} \frac{d}{d t_{i}}\left[F_{t}\left(t_{i}\right)\right)^{n-1}\right]-\left(F_{t}\left(t_{i}\right)\right)^{n-1}=t_{i} \frac{d}{d t_{i}}\left[F_{t}\left(t_{i}\right)\right)^{n-1}\right],
$$

Due to Equation (37) and $\mathrm{K}_{\mathrm{i}}=\mathrm{U}_{\mathrm{i}}\left(\mathrm{t}_{\mathrm{i}}\right)\left(\mathrm{F}_{\mathrm{t}}\left(\mathrm{t}_{\mathrm{i}}\right)\right)^{\mathrm{n}-1}$,

$$
\left.\frac{d}{d t_{i}}\left[U_{i}\left(t_{i}\right)\left(F_{t}\left(t_{i}\right)\right)^{n-1}\right]=\frac{d K_{i}}{d t_{i}}=t_{i} \frac{d}{d t_{i}}\left[F_{t}\left(t_{i}\right)\right)^{n-1}\right],
$$

Change $t_{i}$ in Equation (38) with $t_{i}^{\prime}$, and by substituting it in $t_{i}^{\prime}$ partial Equation (34):

$$
\begin{gathered}
\left.\left.\left.\frac{\partial \pi_{i}\left(t_{i}, t_{i}^{\prime}\right)}{\partial t_{i}^{\prime}}=t_{i} \frac{d}{d t_{i}^{\prime}}\left[F_{t}\left(t_{i}^{\prime}\right)\right)^{n-1}\right]-\frac{d}{d t_{i}^{\prime}}\left[U_{i}\left(t_{i}^{\prime}\right)\left(F_{t}\left(t_{i}^{\prime}\right)\right)^{n-1}\right]=t_{i} \frac{d}{d t_{i}^{\prime}}\left[F_{t}\left(t_{i}^{\prime}\right)\right)^{n-1}\right]-t_{t_{i}^{\prime}} \frac{d}{d t_{i}^{\prime}}\left[F_{t}\left(t_{i}^{\prime}\right)\right)^{n-1}\right]= \\
\left.\left.\left(t_{i}-t_{i}^{\prime}\right) \frac{d}{d t_{i}^{\prime}}\left[F_{t}\left(t_{i}^{\prime}\right)\right)^{n-1}\right]=\left(t_{i}-t_{i}^{\prime}\right)(n-1) F_{t}\left(t_{i}^{\prime}\right)\right)^{n-2} F_{t_{t}^{\prime}}\left(t_{i}^{\prime}\right),
\end{gathered}
$$

When energy supplier wins the auction, the equation of its derivative satisfies:

$$
\frac{\partial \pi_{\mathrm{i}}\left(\mathrm{t}_{\mathrm{i}}, \mathrm{t}_{\mathrm{i}}^{\prime}\right)}{\partial \mathrm{t}_{\mathrm{i}}^{\prime}}=0,
$$

At the same time, $\mathrm{F}_{\mathrm{t}}\left(\mathrm{t}_{\mathrm{i}}\right)$ is an increasing function and greater than 0 , so the only solution of Equation (39) is $t_{i}=t_{i}^{\prime}$. Theorem 5 is proved.

The above analysis assumes that other energy suppliers remain unchanged. When other energy suppliers also consider external returns and change their own bidding type, the optimal strategy remains unchanged. The reasons are as follows; firstly, when all of the energy suppliers change the type with the same direction, the results of the auction, and the results of the optimal strategy to win the auction don't differ. Secondly, for the winning energy supplier, it will not gain more profits since it changes the type, which raises prices with their project costs increased as well. Therefore, the optimal strategy for energy supplier is participating in the auction based on their own real type.

By Theorem 5, although the external returns after winning the bid can increase the energy supplier's returns, the energy supplier's optimal bidding price is in accordance with their own real situation. If energy supplier does not bid in real terms, due to the existence of external returns, energy supplier will choose to reduce the tender price or to improve the quality of the bid to win the auction. When the energy supplier provides the same quality but lower bidding price, the energy supplier's profits will decline. When the energy supplier provides the same price but higher quality bidding, it will increase the cost risk of energy supplier. As the cost increases, the energy supplier will reduce the quality of the micro-grid project, and may even terminate the implementation of the micro-grid project, when the returns of default are greater than the returns of the implementation. Both of these conditions undermine the benefits of the project owner and the energy supplier. In summary, although the energy supplier will reduce the price or improve the quality in practice in consideration of external returns, the optimal way for the energy supplier that participates in the micro-grid project bidding is 
to bid in accordance with their real situation. In this way, the returns of project owners and energy suppliers are optimal, thus maximizing total social benefits.

Theorem 6. Multi-attribute micro-grid project reverse auction mechanism in this article is an effective auction mechanism, in line with individual rational and incentive compatibility principle.

The mechanism design theory holds that an effective mechanism must satisfy the principle of individual rationality and incentive compatibility. From the Theorems 1 and 4, both the project owners and energy supplier are participating in micro-grid project auction to maximize their own returns, which meets the principle of individual rationality. At the same time, it can be seen from Theorems 4 and 5 that the energy supplier will bid according to its own real situation, not be affected by external returns, in which the individual return and collective return are in the optimal state, to meet the incentive compatibility principle. Therefore, the multi-attribute micro-grid project reverse auction mechanism in this article is an effective auction mechanism.

\section{Numerical Analysis}

Numerical simulation is carried out through Matlab programming to make an in-depth analysis of the multi-attribute reverse auction mechanism of micro-grid project transfer.

Assuming that there is a project owner who needs to build micro-grid project, in order to pursue professional efficiency, project owner will auction the franchise of the micro-grid project. Assuming the project owner publishes the tender information, where the highest carbon emissions is $\mathrm{E}=1$, the implied value coefficient of power quality, energy storage quality and carbon emissions, and the pre-bid cost are $\mathrm{v}_{\mathrm{q}}=1.3, \mathrm{v}_{\mathrm{s}}=1.2, \mathrm{v}_{\mathrm{e}}=1.1$, and $\mathrm{C}_{\mathrm{f}}=0.01$, respectively. After the announced the tender plan, there are two energy suppliers $(n=2)$ to participate in the bidding. We do not know the specific values of their $\mathrm{q}_{\mathrm{i}}, \mathrm{s}_{\mathrm{i}}$, and $\mathrm{e}_{\mathrm{i}}$, but know the $\mathrm{q}_{\mathrm{i}}, \mathrm{s}_{\mathrm{i}}$, and $\mathrm{e}_{\mathrm{i}}$ of energysupplier obey the uniform distribution $[0,1]$, and the cost coefficient of $\mathrm{q}_{\mathrm{i}}, \mathrm{s}_{\mathrm{i}}$, and $\mathrm{e}_{\mathrm{i}}$, are $\mathrm{c}_{\mathrm{q}}=0.3, \mathrm{c}_{\mathrm{s}}=0.2, \mathrm{c}_{\mathrm{e}}=0.1$. Then, we analyze the stakeholder strategy and the impact of related factors.

\subsection{Strategy of Energy Supplier}

In order to explore the energy supplier's strategy, we first calculate the distribution of energy supplier types. According to the formula $F_{t}\left(t_{i}\right)$, the cumulativedistribution function of the energy supplier's type is:

$$
\mathrm{F}_{\mathrm{t}}\left(\mathrm{t}_{\mathrm{i}}\right)=\left\{\begin{array}{lr}
0 & \mathrm{t}_{\mathrm{i}}<0 \\
\frac{1}{6} \mathrm{t}_{\mathrm{i}}^{3} & 0 \leq \mathrm{t}_{\mathrm{i}}<1 \\
-\frac{1}{3} \mathrm{t}_{\mathrm{i}}^{3}+\frac{3}{2} \mathrm{t}_{\mathrm{i}}^{2}-\frac{3}{2} \mathrm{t}_{\mathrm{i}}+\frac{1}{2} & 1 \leq \mathrm{t}_{\mathrm{i}}<2 \\
\frac{1}{6} \mathrm{t}_{\mathrm{i}}^{3}-\frac{3}{2} \mathrm{t}_{\mathrm{i}}^{2}+3 \mathrm{t}_{\mathrm{i}}-2 & 2 \leq \mathrm{t}_{\mathrm{i}} \leq 3 \\
1 \mathrm{t}_{\mathrm{i}}>3 &
\end{array}\right.
$$

Then, we calculate the bidding price for energy supplier. When in equilibrium, $t_{i}\left(F_{t}\left(t_{i}\right)\right)^{n-1}-C_{f}=0$. When the number of energy supplier $n=2, t_{m}=0.49$. Apply $t_{m}$ and $F_{t}\left(t_{i}\right)$ in price formula, we'll get the price of the expression:

$$
p_{i}=\left\{\begin{array}{lr}
\text { Not to participate in the bidding } & t_{i} \leq 0.49 \\
0.3 q_{i}+0.2 s_{i}+0.1\left(1-e_{i}\right)+\frac{t_{i}^{4}-0.06}{4 t_{i}^{3}} & 0.49<t_{i}<1 \\
0.3 q_{i}+0.2 s_{i}+0.1\left(1-e_{i}\right)+\frac{-t_{i}^{4}+6 t_{i}^{3}-9 t_{i}^{2}+6 t_{i}-1.44}{-4 t_{i}^{3}+18 t_{i}^{2}-18 t_{i}+6} & 1 \leq t_{i}<2 \\
0.3 q_{i}+0.2 s_{i}+0.1\left(1-e_{i}\right)+\frac{t_{i}^{4}-12 t_{i}^{3}+36 t_{i}^{2}-48 t_{i}-16.33}{t_{i}^{3}-36 t_{i}^{2}-72 t_{i}-48} & 2 \leq t_{i} \leq 3
\end{array}\right.
$$


The bidding price can be calculated according to above $\mathrm{p}_{\mathrm{i}}$ equation and specific values of $\mathrm{q}_{\mathrm{i}}, \mathrm{s}_{\mathrm{i}}$, $e_{i}$ and $t_{i}$. At the same time, it can be seen from above equation that the energy supplier determines whether to participate in the auction according to its own type $t_{\mathrm{i}}$.

Then, we draw pictures to further analyze the impact of $t_{i}, r_{i}, o_{i}$ on energy supplier's strategy. Figure 2a is drawn accordingly to above expression. As from Figure 2a, with the improvement of energy supplier's type, the tender price gradually increases first and then declining step by step. This is true. As the power quality and energy storage capacity gradually increase to a certain extent and carbon emissions is reduced to a certain extent, the cost will increase sharply, resulting into the dramatic increase of tender price. When the type increases to a certain extent, the bidding price reduced in a cascade, indicating that the bidding price of the energy supplier has the optimal boundary. The optimal boundary is relatively low due to the small calculation parameters in this article. As a result, Figure 2a shows that different projects have the optimal price and optimal energy supplier types. Figure $2 b$ is drawn by substituting values into Equation (17). It can be seen from Figure $2 b$ that the equilibrium type is positively affected by the utilization rate of renewable energy and comprehensive utilization rate of energy, the Theorem 2 is verified.

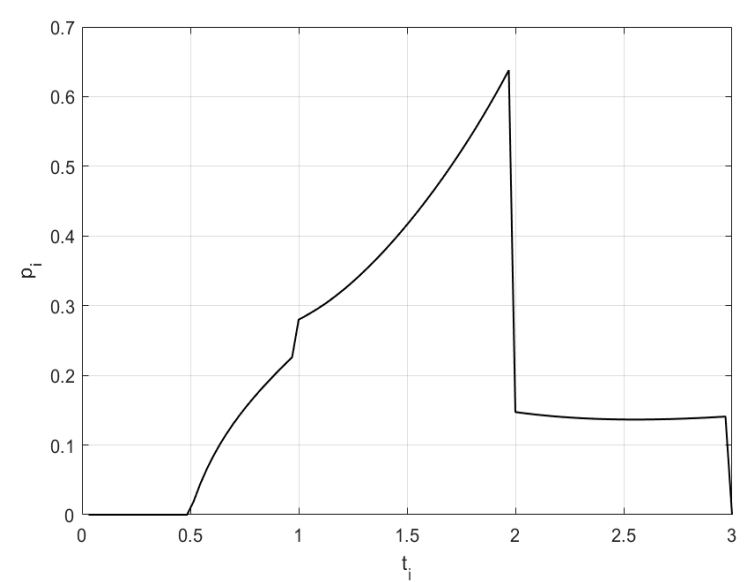

(a)

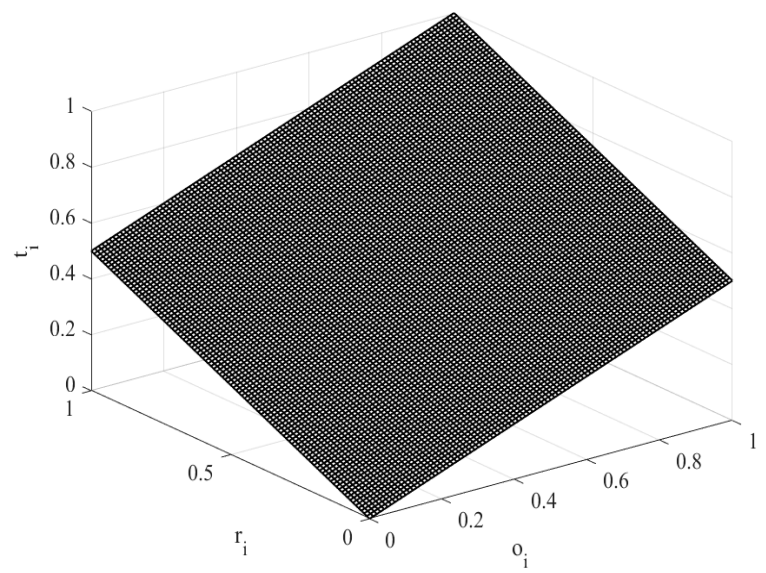

(b)

Figure 2. (a) The relationship between type of energy supplier and bidding price; (b) The relationship among $r_{i}, o_{i}$ and $t_{m}$.

\subsection{Strategy of Project Owner}

The project owner chooses the winning party according to the type of energy supplier, so in order to analyze the project owner's strategy, we analyze the relationship between the type of energy supplier and the revenue of both parties. First, we calculate the specific expression of $U_{i}$ and $\pi_{i}$. By Substituting values of $\mathrm{p}_{\mathrm{i}}, \mathrm{q}_{\mathrm{i}}, \mathrm{s}_{\mathrm{i}}, \mathrm{e}_{\mathrm{i}}$ into expressions of $\mathrm{U}_{\mathrm{i}}$ and $\pi_{\mathrm{i}}$, we get:

$$
\begin{aligned}
& U_{i}=\left\{\begin{array}{lr}
t_{i}-\frac{t_{i}^{4}-0.06}{4 t_{i}^{3}} & 0.49<t_{i}<1 \\
t_{i}-\frac{-t_{i}^{4}+6 t_{i}^{3}-9 t_{i}^{2}+6 t_{i}-1.44}{-4 t_{i}^{3}+18 t_{i}^{2}-18 t_{i}+6} & 1 \leq t_{i}<2 \\
t_{i}-\frac{t_{i}^{4}-12 t_{i}^{3}+36 t_{i}^{2}-48 t_{i}-16.33}{t_{i}^{3}-36 t_{i}^{2}-72 t_{i}-48} & 2 \leq t_{i} \leq 3
\end{array}\right. \\
& \pi_{\mathrm{i}}=\left\{\begin{array}{lr}
\frac{\mathrm{t}_{\mathrm{i}}^{4}-0.06}{4 t_{\mathrm{i}}^{3} * 1 / 6 \mathrm{t}_{\mathrm{i}}^{3}}-\frac{\mathrm{t}_{\mathrm{i}}^{4}+6 \mathrm{t}_{\mathrm{i}}^{3}-9 \mathrm{t}_{\mathrm{i}}^{2}+6 \mathrm{t}_{\mathrm{i}}-1.44}{\left(-4 \mathrm{t}_{\mathrm{i}}^{3}+18 \mathrm{t}_{\mathrm{i}}^{2}-18 \mathrm{t}_{\mathrm{i}}+6\right) *\left(-1 / 3 \mathrm{t}_{\mathrm{i}}^{3}+3 / 2 \mathrm{t}_{\mathrm{i}}^{2}-3 / 2 \mathrm{t}_{\mathrm{i}}+1 / 2\right)} & 0.49<\mathrm{t}_{\mathrm{i}}<1 \\
\frac{\left(\mathrm{t}_{\mathrm{i}}-12 \mathrm{t}_{\mathrm{i}}^{3}+36 \mathrm{t}_{\mathrm{i}}^{2}-48 \mathrm{t}_{\mathrm{i}}-16.33\right)}{\left(\mathrm{t}_{\mathrm{i}}^{3}-36 \mathrm{t}_{\mathrm{i}}^{2}-72 \mathrm{t}_{\mathrm{i}}-48\right) *\left(1 / 6 \mathrm{t}_{\mathrm{i}}^{3}-3 / 2 \mathrm{t}_{\mathrm{i}}^{2}+3 \mathrm{t}_{\mathrm{i}}-2\right)} & 2 \leq \mathrm{t}_{\mathrm{i}}<2 \\
& 2 \leq 3
\end{array}\right.
\end{aligned}
$$


The specific income of project owner and energy supplier can be calculated based on the above formula and $t_{i}$. Then, in order to derive the strategy of project owner, we draw pictures to further analyze the impact of $t_{i}$ on $U_{i}$ and $\pi_{i}$. Figure $3 a, b$ can be drawn by above expression $U_{i}$ and $\pi_{i}$. As shown in Figure 3a,b, the returns of the project owner and the energy supplier increases as the type of energy supplier increases, the Theorem 4 is verified. Figure $3 b$ also shows that the returns of the energy supplier increases as its type increase until it reaches a certain value when it begins to fall. This is reasonable, because for the project owner, with the upgrade of energy supplier's type, project owner will get more benefits; but for energy supplier, with the type upgrade to a certain extent, they will be faced with high costs and technical difficulty, which negatively affects the benefits of energy supplier. It can also be seen from Figure 3a,b that the type of energy supplier is high at equilibrium, and from the previous analysis we can know that the corresponding price is also high at this time. In conclusion, it can be found that the balance of micro-grid project transfer auction is the optimal combination of quality attributes and price, which is obviously different from the previous lowest price get win, and the returns of project owner and energy supplier is also at the optimal level.

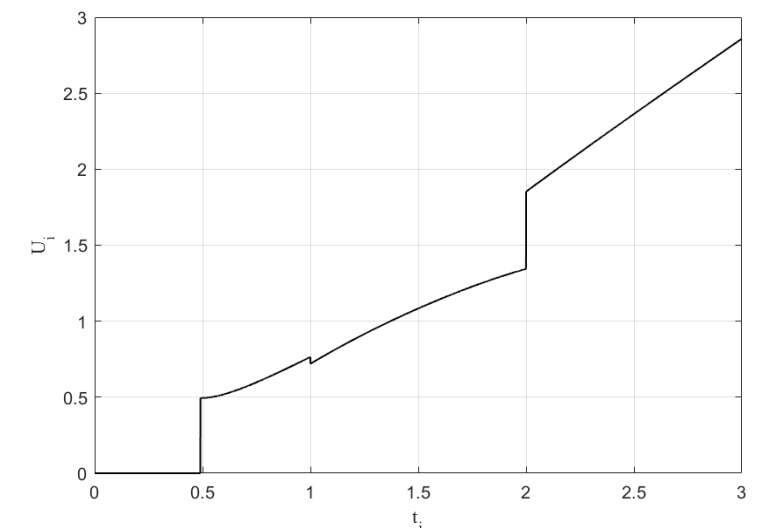

(a)

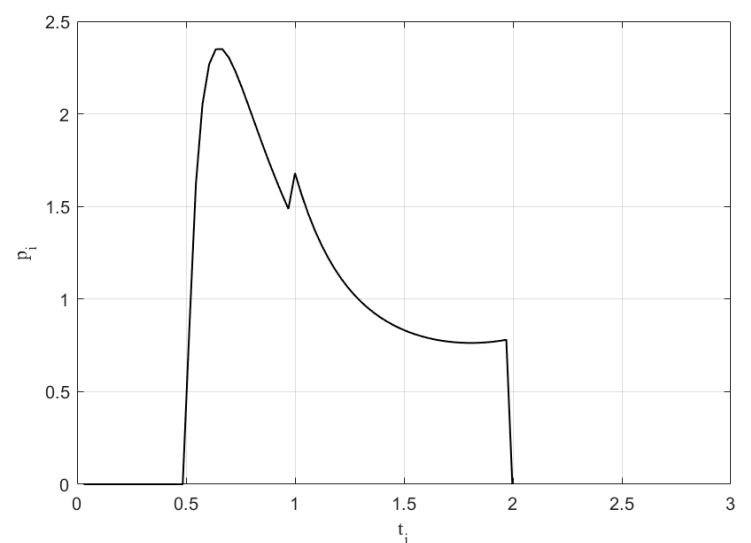

(b)

Figure 3. (a) The relationship between type of energy supplier and returns of project owner; (b) The relationship between benefits and type of energy supplier.

\subsection{Effect of Cost and Quantity}

We draw pictures to further analyze the impact of pre-bid costs and number of energy supplier on auction strategy. Similarly, Figure $4 \mathrm{a}, \mathrm{b}$ can be drawn by the equilibrium conditions calculating and expressions. As can be seen from Figure $4 a, b$, with the increasing of the pre-bid cost and the number of energy suppliers, the type of energy supplier also increases in equilibrium, Theorem 3 is verified. It can also be seen from the Figure $4 a, b$ that when $C_{f}$ and $n$ increase to a certain value, the equilibrium type tends to a value, indicating that the values of $C_{f}$ and $n$ are not the bigger the better, but there is an optimal value boundary. This is true, because as a sinking cost, the pre-bid cost is only required to meet the proper level that can ensure the previous project research and design. Therefore, higher pre-bid cost will only increase the cost of energy supplier, and is not necessary for the project owner. At the same time, the number of energy suppliers involved in the auction is not too much, too many energy suppliers will not only increase the cost of the project owner's audit, but also affect the quality of the energy supplier involved in the auction. In summary, the project owner can control the pre-bid costs and the number of energy suppliers participate in the auction to improve the quality of micro-grid project auction. 


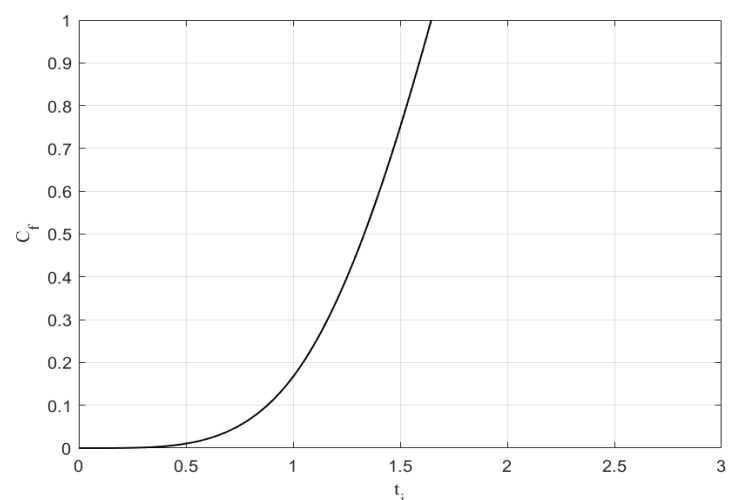

(a)

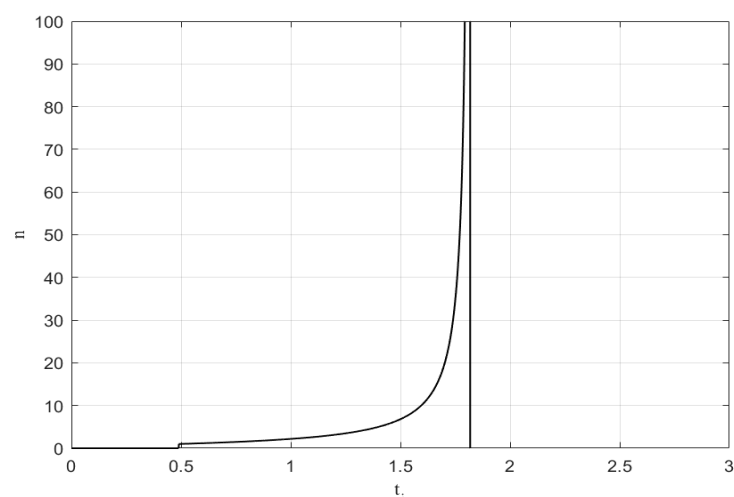

(b)

Figure 4. (a) The relationship between pre-bid cost and equilibrium type of energy supplier; (b) The relationship between number of tender energy suppliers and equilibrium type of energy suppliers.

\section{Conclusions}

This paper studies the auction mechanism of micro-grid project transfer, and draws some interesting conclusions. Firstly, this paper proposes the use of power quality, energy storage quality, and carbon emissions to distinguish the types of energy suppliers, and take the energy supplier's bidding price as a function of power quality, energy quality, and carbon emissions to derive the energy supplier's optimal bidding price. Furthermore, it is proved that the bidding price is the sub-game Nash equilibrium solution of the auction game. Secondly, in the equilibrium state, through the proof and the numerical analysis shows that with the increase of number of energy suppliers participating in the auction or the increase of pre-bid cost, the energy supplier's equilibrium type will be improved. Therefore, it is reasonable for the project owner to set a higher pre-bid cost and to control the appropriate number of energy suppliers participating in the auction. Thirdly, the analysis shows that both the benefits of energy suppliers and project owners will increase as the type of energy providers increases. Fourthly, this paper deduces that the optimal bidding strategy of energy suppliers is to bid according to the actual power quality, energy storage quality, carbon emission, and the optimal price; the optimal strategy of the project owner is to choose the winner of the auction based on the type of energy supplier, that is, to choose the energy supplier with the best combination of power quality, energy storage quality, carbon emissions, and price as the winner of the auction. Finally, this paper points out that the multi-attribute reverse auction mechanism is an effective mechanism for micro-grid project transfer when there is no collusion between energy suppliers and their risk preference is neutral and symmetry. Through the numerical analysis, it is revealed that the project owner actually chooses the energy supplier with higher bidding price. This is contrary to the intuition, but it is reasonable, because the higher tender price of energy providers is also a better type of supplier, that is, the energy supplier with the best combination of power quality, energy storage quality, carbon emissions, and price. Therefore, the project owner is no longer only take the tender price as the standard for selecting energy suppliers, and will consider the power quality, energy storage quality, carbon emissions and prices, and other aspects. These results provide an important reference for the micro-grid project transfer.

Acknowledgments: This work is supported by the National Social Science Foundation of China (Grant no. 14AZD130).

Author Contributions: Yong Long and Yu Wang conceived and designed the study; Yu Wang wrote the first draft of the paper; Yong Long and Chengrong Pan offered guidance, support, and feedback for improving the paper.

Conflicts of Interest: The authors declare no conflict of interest. 


\section{Nomenclature}

$v_{\mathrm{q}} \quad$ Preference for power quality

$v_{s} \quad$ Preference for energy storage quality

$\mathrm{v}_{\mathrm{e}} \quad$ Preference for carbon emissions

$\mathrm{C}_{\mathrm{f}} \quad$ Pre-bid costs

E Acceptable maximum levels of carbon emissions

$\mathrm{c}_{\mathrm{q}} \quad$ Unit power quality cost

$c_{\mathrm{s}} \quad$ Unit energy storage quality cost

$\mathrm{Ce}_{\mathrm{C}} \quad$ Carbon emissions cost

$\mathrm{q}_{\mathrm{i}} \quad$ Power quality provided by energy supplier $\mathrm{i}$

$\mathrm{s}_{\mathrm{i}} \quad$ Energy storage quality provided by energy supplier $\mathrm{i}$

$\mathrm{e}_{\mathrm{i}} \quad$ Carbon emissions provided by energy supplier $\mathrm{i}$

$\mathrm{p}_{\mathrm{i}} \quad$ Bidding price

$t_{i} \quad$ Type of energy supplier $i$

$q_{1} \quad$ Lower limits of power quality

$\mathrm{q}_{\mathrm{h}} \quad$ Upper limits of power quality

$\mathrm{s}_{1} \quad$ Lower limits of energy storage quality

$s_{h} \quad$ Upper limits of energy storage quality

$\mathrm{e}_{1} \quad$ Lower limits of carbon emissions

$\mathrm{e}_{\mathrm{h}} \quad$ Upper limits of carbon emissions

$r_{i} \quad$ Utilization rate of renewable energy

$\mathrm{O}_{\mathrm{i}} \quad$ Comprehensive utilization rate of energy

$t_{m} \quad$ Type of energy supplier at equilibrium

$\mathrm{q}_{\mathrm{m}} \quad$ Power quality at equilibrium

$\mathrm{s}_{\mathrm{m}} \quad$ Energy storage quality at equilibrium

$\mathrm{e}_{\mathrm{m}} \quad$ Carbon emissions at equilibrium

\section{References}

1. National Energy Board of China. Administrative Measures for Micro-Grid (Exposure Draft). Available online: http://zfxxgk.nea.gov.cn/auto84/201702/t20170209_2561.htm (accessed on 7 February 2017).

2. European Commission. A Policy Framework for Climate and Energy in the Period from 2020 to 2030. Available online: http:/ / eur-lex.europa.eu/legal-content/EN/TXT/?uri=CELEX:52014DC0015 (accessed on 4 March 2017).

3. Lidula, N.W.A.; Rajapakse, A.D. Microgrids research: A review of experimental microgrids and test systems. Renew. Sustain. Energy Rev. 2011, 15, 186-202. [CrossRef]

4. Ustun, T.S.; Ozansoy, C.; Zayegh, A. Recent developments in microgrids and example cases around the world-A review. Renew. Sustain. Energy Rev. 2011, 15, 4030-4041. [CrossRef]

5. National Energy Board. Guiding Opinions on Promoting the Construction of Micro-Grid Demonstration Project. Available online: http://zfxxgk.nea.gov.cn/auto87/201507/t20150722_1949.htm (accessed on 14 March 2017).

6. National Development and Reform Commission of China; National Energy Board of China. The 13th Five-Year Plan for Electric Power Development. Available online: http:/ /www.nea.gov.cn/2017--01/17/c_ 135989417.htm (accessed on 13 March 2017).

7. Moghaddam, A.A.; Seifi, A.; Niknam, T.; Pahlavani, M.R.A. Multi-objective operation management of a renewable MG (micro-grid) with back-up micro-turbine/fuel cell/battery hybrid power source. Energy 2011, 36, 6490-6507. [CrossRef]

8. Bahmani-Firouzi, B.; Azizipanah-Abarghooee, R. Optimal sizing of battery energy storage for micro-grid operation management using a new improved bat algorithm. Int. J. Electr. Power 2014, 56, 42-54. [CrossRef]

9. Vardakas, J.S.; Zorba, N.; Verikoukis, C.V. Power demand control scenarios for smart grid applications with finite number of appliances. Appl. Energy 2016, 162, 83-98. [CrossRef] 
10. Kamel, R.M.; Alsaffar, M.A.; Habib, M.K. Novel and simple scheme for Micro-Grid protection by connecting its loads neutral points: A review on Micro-Grid protection techniques. Renew. Sustain. Energy Rev. 2016, 58, 931-942. [CrossRef]

11. Zenginis, I.; Vardakas, J.S.; Echave, C.; Morató, M.; Abadal, J.; Verikoukis, C.V. Cooperation in microgrids through power exchange: An optimal sizing and operation approach. Appl. Energy 2017, 203, $972-981$. [CrossRef]

12. Boait, P.; Gammon, R.; Advani, V.; Wade, N.; Greenwood, D.; Davison, P. ESCoBox: A Set of Tools for Mini-Grid Sustainability in the Developing World. Sustainability 2017, 9, 738. [CrossRef]

13. Eddy, Y.S.F.; Gooi, H.B.; Chen, S.X. Multi-Agent System for Distributed Management of Microgrids. IEEE Trans. Power Syst. 2014, 30, 24-34. [CrossRef]

14. Kim, H.; Bae, J.; Baek, S.; Nam, D.; Cho, H.; Chang, H.J. Comparative Analysis between the Government Micro-Grid Plan and Computer Simulation Results Based on Real Data: The Practical Case for a South Korean Island. Sustainability 2017, 9, 197. [CrossRef]

15. Guo, S.; Zhao, H.R.; Zhao, H.R. The Most Economical Mode of Power Supply for Remote and Less Developed Areas in China: Power Grid Extension or Micro-Grid? Sustainability 2017, 9, 910. [CrossRef]

16. Zeng, M.; Zhan, X.H.; Jia, X.X.; Yang, Y.Q.; Li, N. Benefit Analysis and Evaluation Model of Smart Micro-grid Technology and Its Application. Water Resource Power 2013, 31, 173-175.

17. Luo, Z.; Gu, W.; Sun, Y.; Yin, X.; Tang, Y.Y.; Yuan, X.D. Performance Analysis of the Combined Operation of Interconnected-BCCHP Microgrids in China. Sustainability 2016, 8, 977. [CrossRef]

18. Long, Y.; Wang, G.T.; Meng, W.D.; Wang, Y. The competing relationship of micro-grid and large-grid and its impact on social welfare effect. J. Chongqing Univ. Nat. Sci. Ed. 2014, 37, 147-152. [CrossRef]

19. Pan, C.R.; Long, Y. Evolutionary Game Analysis of Cooperation between Microgrid and Conventional Grid. Math. Probl. Eng. 2015, 6, 1-10. [CrossRef]

20. Alibhai, Z.; Gruver, W.A.; Kotak, D.B.; Sabaz, D. Distributed coordination of micro-grids using bilateral contracts. In Proceedings of the IEEE International Conference on Systems, Man and Cybernetics, The Hague, The Netherlands, 10-13 October 2004; pp. 1990-1995.

21. Maity, I.; Rao, S. Simulation and Pricing Mechanism Analysis of a Solar-Powered Electrical Microgrid. IEEE Syst. J. 2010, 4, 275-284. [CrossRef]

22. Mayr, D.; Schmidt, J.; Schmid, E. The potentials of a reverse auction in allocating subsidies for cost-effective roof-top photovoltaic system deployment. Energy Policy 2014, 69, 555-565. [CrossRef]

23. Butler, L.; Neuhoff, K. Comparison of Feed in Tariff, Quota and Auction Mechanisms to Support Wind Power Development. Renew. Energy 2008, 33, 1854-1867. [CrossRef]

24. Kreiss, J.; Ehrhart, K.M.; Haufe, M.C. Appropriate design of auctions for renewable energy supportPrequalification sand penalties. Energy Policy 2016, 101, 512-520. [CrossRef]

25. National Energy Board of China. Circular on Actively Promoting the Mode of Cooperation between Government and Social Capital in the Energy Sector. Available online: http:/ / zfxxgk.nea.gov.cn/auto81/ 201604/t20160413_2232.htm?keywords= (accessed on 18 April 2017).

26. Liu, S.L.; Wang, M.X. Multi-Attribute Procurement Auction Theory and Application: A Review with Comments. Chin. J. Manag. Sci. 2009, 17, 183-192. [CrossRef]

27. Fang, D.B.; Wang, X.J.; Wu, J.F. Second price auction for electrical procurement considering carbon emission in power generation market. Syst. Eng.-Theor. Pract. 2013, 33, 1984-1992. [CrossRef]

28. Ma, B.J.; Xu, B.W.; Xu, C. Muti-attribute Bidding Mechanism Design for Warranted Lifetime Products: A case study on Large Medical Equipment. Chin. J. Manag. Sci. 2013, 21, 112-120. [CrossRef]

29. Mastropietro, P.; Batlle, C.; Barroso, L.A.; Rodilla, P. Electricity auctions in South America: Towards convergence of system adequacy and RES-E support. Renew. Sustain. Energy Rev. 2014, 40, 375-385. [CrossRef]

30. Kylili, A.; Fokaides, P.A. Competitive auction mechanisms for the promotion renewable energy technologies: The case of the $50 \mathrm{MW}$ photovoltaics projects in Cyprus. Renew. Sustain. Energy Rev. 2015, 42, $226-233$. [CrossRef]

31. Marufu, A.M.C.; Kayem, A.V.D.M.; Wolthusen, S.D. Circumventing Cheating on Power Auctioning in Resource Constrained Micro-Grids. In Proceedings of the IEEE International Conference on Smart City, Sydney, Australia, 12-14 December 2016; pp. 1380-1387. 
32. Ferruzzi, G.; Cervone, G.; Monache, L.D.; Graditi, G.; Jacobone, F. Optimal bidding in a Day-Ahead energy market for Micro Grid under uncertainty in renewable energy production. Energy 2016, 106, 194-202. [CrossRef]

33. Eberhard, A.; Kåberger, T. Renewable energy auctions in South Africa outshine feed-in tariffs. Energy Sci. Eng. 2016, 4, 190-193. [CrossRef]

34. Atalay, Y.; Kalfagianni, A.; Pattberg, P. Renewable energy support mechanisms in the Gulf Cooperation Council states: Analyzing the feasibility of feed-in tariffs and auction mechanisms. Renew. Sustain. Energy Rev. 2017, 72, 723-733. [CrossRef]

35. Gephart, M.; Klessmann, C.; Wigand, F. Renewable energy auctions-When are they (cost-) effective? Energy Environ. 2017, 28, 145-165. [CrossRef]

36. Voss, A.; Madlener, R. Auction Schemes, Bidding Strategies and the Cost-Optimal Level of Promoting Renewable Electricity in Germany. ENERG J. 2017, 38, 229-264. [CrossRef]

2017 by the authors. Licensee MDPI, Basel, Switzerland. This article is an open access article distributed under the terms and conditions of the Creative Commons Attribution (CC BY) license (http://creativecommons.org/licenses/by/4.0/). 